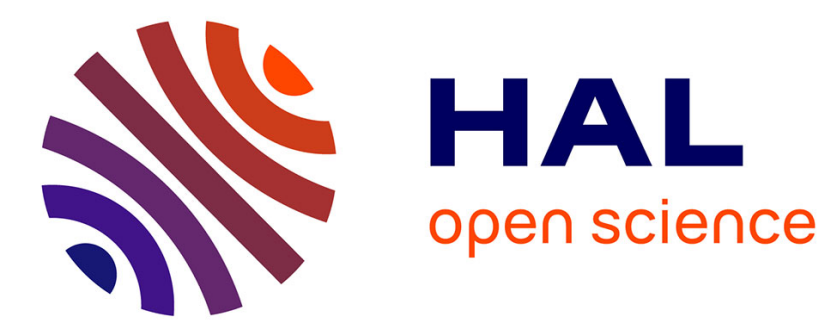

\title{
Mapping gas exchanges in headwater streams with membrane inlet mass spectrometry
}

Camille Vautier, Ronan Abherve, Thierry Labasque, Anniet M. Laverman, Aurélie Guillou, Eliot Chatton, Patrick Dupont, Luc Aquilina, Jean-Raynald de Dreuzy

\section{To cite this version:}

Camille Vautier, Ronan Abherve, Thierry Labasque, Anniet M. Laverman, Aurélie Guillou, et al.. Mapping gas exchanges in headwater streams with membrane inlet mass spectrometry. Journal of Hydrology, 2020, 581, pp.124398. 10.1016/j.jhydrol.2019.124398 . insu-02403865

\section{HAL Id: insu-02403865 https://hal-insu.archives-ouvertes.fr/insu-02403865}

Submitted on 11 Dec 2019

HAL is a multi-disciplinary open access archive for the deposit and dissemination of scientific research documents, whether they are published or not. The documents may come from teaching and research institutions in France or abroad, or from public or private research centers.
L'archive ouverte pluridisciplinaire HAL, est destinée au dépôt et à la diffusion de documents scientifiques de niveau recherche, publiés ou non, émanant des établissements d'enseignement et de recherche français ou étrangers, des laboratoires publics ou privés. 


\section{Journal Pre-proofs}

Research papers

Mapping gas exchanges in headwater streams with membrane inlet mass spectrometry

Camille Vautier, Ronan Abhervé, Thierry Labasque, Anniet M. Laverman, Aurélie Guillou, Eliot Chatton, Pascal Dupont, Luc Aquilina, Jean-Raynald de Dreuzy

PII: S0022-1694(19)31133-3

DOI: https://doi.org/10.1016/j.jhydrol.2019.124398

Reference:

HYDROL 124398

To appear in:

Journal of Hydrology

Received Date:

26 July 2019

Revised Date:

20 November 2019

Accepted Date:

22 November 2019

Please cite this article as: Vautier, C., Abhervé, R., Labasque, T., Laverman, A.M., Guillou, A., Chatton, E., Dupont, P., Aquilina, L., de Dreuzy, J-R., Mapping gas exchanges in headwater streams with membrane inlet mass spectrometry, Journal of Hydrology (2019), doi: https://doi.org/10.1016/j.jhydrol.2019.124398

This is a PDF file of an article that has undergone enhancements after acceptance, such as the addition of a cover page and metadata, and formatting for readability, but it is not yet the definitive version of record. This version will undergo additional copyediting, typesetting and review before it is published in its final form, but we are providing this version to give early visibility of the article. Please note that, during the production process, errors may be discovered which could affect the content, and all legal disclaimers that apply to the journal pertain.

(C) 2019 Published by Elsevier B.V. 
1

2

3

4

5

6 a Univ Rennes, CNRS, Géosciences Rennes, UMR 6118, 35000 Rennes, France

7

9

10

11

12 Corresponding Author

$13 *$ camille.vautier@univ-rennes1.fr

14 Present Addresses

$15{ }^{1}$ Sorbonne Universités, UPMC Univ Paris 06, CNRS, Laboratoire d'Océanographie

16 Microbienne (LOMIC), Observatoire Océanologique, Banyuls/mer, France spectrometry

Jean-Raynald de Dreuzy ${ }^{a, c}$

UMS 3343, 35000 Rennes, France

${ }^{d}$ Univ Rennes, CNRS, Ecobio, UMR 6553, 35000 Rennes, France

e LGCGM, INSA Rennes, 35000 Rennes, France 


\section{ABSTRACT}

18 Using continuous injections of helium coupled to in-situ continuous flow membrane

19 inlet mass spectrometry (CF-MIMS), we mapped the gas exchanges along two low-

20 slope headwater streams having discharges of $25 \mathrm{~L} \mathrm{~s}^{-1}$ and $90 \mathrm{~L} \mathrm{~s}^{-1}$. Mean reaeration

21 rate coefficients $\left(k_{2}\right)$ were estimated at $130 \mathrm{~d}^{-1}$ and $60 \mathrm{~d}^{-1}$, respectively. Our study

22 revealed that gas exchanges along headwater streams are highly heterogeneous. The

23 variable morphology of the streambed causes gas exchanges to be focused into small

24 areas, namely small cascades made up of stones or wood, with reaeration rate

25 coefficients up to 40 times higher than in low-turbulent zones. As such, cascades

26 appear to be hot spots for both oxygenation and greenhouse gases emissions.

27 Additional $\mathrm{O}_{2}$ and $\mathrm{CO}_{2}$ measurements effectively showed fast exchanges between

28 the stream and the atmosphere in the cascades, following the partial pressure

29 gradients. These cascades allow a fast oxygenation of the eutrophic streams depleted

30 in $\mathrm{O}_{2}$, which sustains respiration. Simultaneously, cascades release the oversaturated

$31 \mathrm{CO}_{2}$ originating from groundwater inputs to the atmosphere. By comparing

32 measured reaeration rate coefficients to ten predictive equations from literature, we

33 showed that all equations systematically underestimate reaeration rate coefficients,

34 with significantly higher discrepancies in cascades than in low-turbulent zones. The

35 inadequate characterization of the processes occurring in cascades causes empirical 
36 equations to have poor predictive capabilities, leading to a global underestimation

37 of $\mathrm{CO}_{2}$ emission from headwater streams. 


\section{$38 \quad$ KEY-WORDS}

$39 \quad-$ headwater stream

$40 \quad-\quad$ membrane inlet mass spectrometry (MIMS)

$41 \quad-$ reaeration

$42 \quad-$ gas exchange

43 - greenhouse gas emission

$44-\mathrm{CO}_{2}$ evasion

45 HIGHLIGHTS

46 - In-situ membrane inlet mass spectrometry allows real-time mapping of gas

$47 \quad$ exchanges along headwater streams.

48 - Gas exchange rate coefficients are highly heterogeneous along low-slope

49 headwater streams.

50 - Predictive equations of gas exchanges are generally reliable in low-turbulent

51 zones, but underestimate gas exchanges in small cascades.

52 - Small cascades can be viewed as hot spots for both stream oxygenation and

$53 \quad \mathrm{CO}_{2}$ emission.

54 - Overlooking small cascades in global $\mathrm{CO}_{2}$ calculations leads to an 55 underestimation of $\mathrm{CO}_{2}$ emissions from headwater catchments. 


\section{INTRODUCTION}

57 Streams continuously exchange gases with the atmosphere. The reaeration process,

58 which characterizes the exchange of oxygen between streams and atmosphere,

59 provides ecosystem services by sustaining in-stream respiration (Aristegi et al. 2009;

60 Knapp et al. 2015). Air-water gas exchanges also control $\mathrm{CO}_{2}, \mathrm{CH}_{4}$ and $\mathrm{N}_{2} \mathrm{O}$ release

61 or uptake by streams (Tranvik et al. 2009) and thus influence the global greenhouse

62 gas budgets of terrestrial systems. Global $\mathrm{CO}_{2}$ emissions from inland water,

63 estimated at $2.9 \mathrm{PgC}^{-1}$, are of the same order of magnitude as terrestrial $\mathrm{C}$ sinks of

$643.1 \mathrm{PgC}^{-1}$. Among inland water $\mathrm{CO}_{2}$ fluxes, recent studies highlighted the

65 importance of inputs from headwater streams, because of their ubiquity (Bishop et

66 al. 2008), their connection to biologically active compartments and their high level

67 of turbulence (Duvert et al. 2018; Natchimuthu et al. 2017; Öquist et al. 2009; Wallin

68 et al. 2011). Crawford et al. (2014) showed that even in a lake-rich landscape of the

69 Northern Highland Lake District (Michigan, US), streams emitted roughly the same

$70 \mathrm{CO}_{2}$ mass as lakes. The same study highlighted that streams may also be substantial

71 sources of $\mathrm{CH}_{4}$ (Crawford et al. 2014). With respect to warming potential, $\mathrm{CH}_{4}$

72 emissions by streams corresponded to $26 \%$ of the total estimated $\mathrm{CO}_{2}$ flux. All these

73 studies call for a better quantification of greenhouse gas emissions in lower-order

74 streams.

75 Quantification of gas exchanges is also crucial in surface water ecology, especially

76 for open-channel metabolism calculations (Aristegi et al. 2009; Knapp et al. 2015).

77 It is a key-point in many hydrogeochemical studies as well, such as radon-based 
78 groundwater discharge estimations (Avery et al. 2018; Cartwright et al. 2014; Cook

79 et al. 2003; Gilfedder et al. 2019; Gleeson et al. 2018). Gas exchange rate 80 coefficients can be measured directly by performing gas tracer release

81 experiments (Benson et al. 2014; Genereux and Hemond 1992; Hall and Madinger

82 2018; Knapp et al. 2019; Wanninkhof et al. 1990). Inert gases such as propane, $\mathrm{SF}_{6}$

83 or helium are injected in the stream, often in conjunction with a non-volatile tracer

84 to account for dispersion and dilution effects. Since these injections are time- and

85 cost-intensive, predictive equations, either empirical (Churchill et al. 1964;

86 Goncalves et al. 2017; Melching and Flores 1999; Tsivoglou and Neal 1976) or

87 process-based (Gualtieri and Gualtieri 2000; Gualtieri et al. 2002), have been

88 developed to propose straightforward estimates of gas exchange rate coefficients.

89 The gas exchange rate coefficients are expressed as a function of hydrodynamic

90 characteristics such as water depth, flow velocity, slope, discharge and in some cases

91 dimensionless numbers (e.g. Froude, Reynolds, Sherwood numbers). A wide

92 diversity of equations may be found in literature, but each equation appears to be

93 specific to the hydrological conditions for which it has been defined, making them

94 poorly reliable at a large scale or in different settings (Melching and Flores 1999;

95 Palumbo and Brown 2014).

96 The diversity of empirical equations existing in literature reflects the variability of

97 gas exchanges in headwater catchments. Lower-order streams are characterized by

98 the great diversity in small-scale morphological structures, including pools, riffles,

99 and cascades that can change over time and that are difficult to represent at larger 
100 scales. In larger rivers, cascades have been shown to trigger gas exchanges by

101 creating air bubbles (Cirpka et al. 1993). High tracer gas losses have been measured

102 in dams (Caplow et al. 2004). Flume experiments have evidenced that spillways and

103 cascades critically increase water oxygenation (Baylar et al. 2006; Khdhiri et al.

104 2014; Tebbutt 1972), generating gas exchanges that may be several orders of

105 magnitudes higher than in low-turbulent channels (Baylar et al. 2006). Drops in $\mathrm{CO}_{2}$

106 partial pressure downstream from waterfalls have additionally been shown in studies

107 focused on global carbon budget estimates (Wallin et al. 2011) and on river water

108 hardness in karstic systems (Chen et al. 2004). In most studies focused on headwater

109 streams, though, a unique gas exchange rate coefficient is estimated for the whole

110 stream, whatever the diversity of its hydrodynamic conditions.

111 Here we focus on headwater streams and investigate the impact of small-scale

112 morphological traits on global predictions of gas exchange rate coefficients and $\mathrm{CO}_{2}$

113 evasion fluxes. We hypothesize that the heterogeneity of the streambed, which is a

114 characteristic feature of headwater streams, explains the difficulty in predicting gas

115 exchanges and $\mathrm{CO}_{2}$ emissions. By coupling continuous helium injections and

116 membrane inlet mass spectrometry, we map gas exchanges along two low slope

117 headwater streams that display a diversity of morphological structures. We

118 additionally measure dissolved $\mathrm{O}_{2}$ and $\mathrm{CO}_{2}$ to characterize the impact of natural

119 cascades and riffles on stream oxygenation and greenhouse gas emissions in

120 headwater catchments. 


\section{MATERIAL AND METHODS}

122 The two headwater streams were selected based on the diversity of their

123 morphological structures (i.e. the presence of low-turbulent zones and cascades).

124 Helium (an inert gas tracer) and $\mathrm{NaCl}$ (a conservative tracer) were injected 125 continuously and monitored at several distances from the injection site using a 126 continuous flow membrane inlet mass spectrometer (CF-MIMS) and an electrical

127 conductivity (EC) probe. Experiments were performed in spring 2018.

$128 \quad 2.1$. Study site

129 The two streams belong to a crystalline catchment located in Pleine-Fougères

130 (Brittany, Western France) (Kolbe et al. 2016). The catchment (figure 1a) is part of 131 the Long-Term Socio-Ecological Research (LTSER) site "Zone Atelier Armorique".

132 Both streams present typical low-slope headwater stream morphologies, featuring

133 small cascades and low-turbulent areas (figure 1c). Both streams are located in

134 agricultural fields and have riverine vegetation dominated by brambles and diverse

135 herbaceous species such as Kentucky bluegrass and buttercups. Stream A (locally

136 called "Le Ronan") is a first-order stream with a mean depth of $0.16 \mathrm{~m}$, a mean width

137 of $0.8 \mathrm{~m}$, and a discharge rate of $25 \mathrm{~L} \mathrm{~s}^{-1}$, as measured by the $\mathrm{NaCl}$ slug injection

138 performed the day of the experiment. Stream B ("Le Petit Hermitage") is a second

139 order stream with a mean depth of $0.25 \mathrm{~m}$, a mean width of $1.8 \mathrm{~m}$, and a discharge

140 rate of $90 \mathrm{~L} \mathrm{~s}^{-1}$. Their streambeds were covered by heterogeneous detrital elements,

141 such as coarse-grain sediments, small rocks and decaying branches, which led their

142 small-scale morphology to be variable (figure $1 \mathrm{~b}$ ). The global slope of the streams 
143 was deduced from the altitude of the upstream and downstream ends of the reach.

144 The precise topography was then determined by measuring the height of each

145 cascade with a tape. Each reach was divided into several uniform sub-reaches (e.g.

146 low-turbulent zone, cascade). Reach A (total length of $52 \mathrm{~m}$ ) showed a succession

147 of low-turbulent zones and small cascades (5 to $15 \mathrm{~cm}$ high). It was divided into 6

148 sub-reaches $\left(A_{1}\right.$ to $\left.A_{6}\right)$ measuring 3 to 12 meters. Reach $B$ (total length of $98 \mathrm{~m}$ ) was

149 flat and homogeneous along its first 95 meters, and displayed a $35 \mathrm{~cm}$ high cascade

150 at its downstream end, between 95 and 98 meters. It was divided into 3 sub-reaches

$151\left(\mathrm{~B}_{1}\right.$ to $\left.\mathrm{B}_{3}\right)$ : two similar segments in the flat zone $\left(\mathrm{B}_{1}\right.$ and $\left.\mathrm{B}_{2}\right)$, and one short segment

152 around the fall $\left(\mathrm{B}_{3}\right)$ (figure $\left.1 \mathrm{~b}\right)$. 


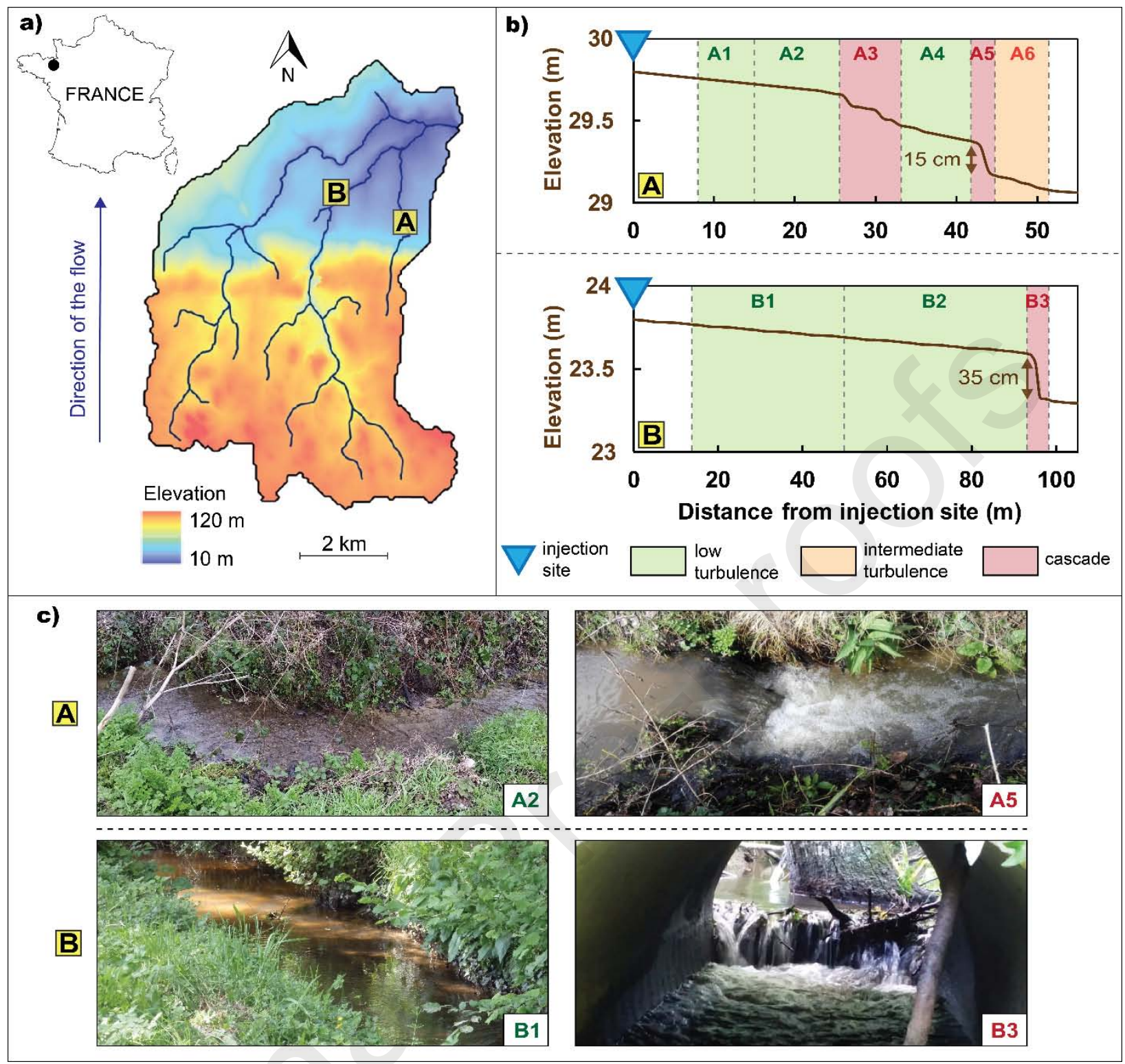

Figure 1. (a) Localization and map of the Pleine-Fougères catchment, (b) Streambed topographic profiles of reaches A and B, and (c) Pictures of the less turbulent zone (left) and of the highest cascade (right) in reach A (up) and in reach B (down). On the topographic profiles (b), dashed lines indicate sub-reaches limits, colors indicate visually-determined turbulence levels of each sub-reach. 


\subsection{Tracer injection}

154 Helium was chosen as gaseous tracer for the following reasons. (1) As a noble gas,

155 it is non-reactive. (2) It is non-toxic. (3) Its concentration in the atmosphere is very

156 low (around $5 \mathrm{ppm}$ ), allowing a high concentration difference between stream and

157 atmosphere during injections. (4) It can be accurately measured with CF-MIMS and

158 gas chromatography. (5) It is highly volatile, increasing the accuracy of degassing

159 estimations. (6) It is not expensive. (7) Unlike other tracers such as $\mathrm{SF}_{6}$ (Benson et

160 al. 2014), it is not a greenhouse gas. A non-volatile conservative tracer was also

161 needed to account for potential dilution due to groundwater discharge (Genereux and

162 Hemond 1990; Kilpatrick et al. 1987; Tobias et al. 2009). We used chloride from

$163 \mathrm{NaCl}$, which is classically chosen for its low cost and simple use (Genereux and

164 Hemond 1990; Genereux and Hemond 1992).

165 Helium and $\mathrm{NaCl}$ were injected continuously at a constant rate for 2 hours in

166 stream A and for 1 hour in stream B. Helium was injected from a $100 \%$ liquid

167 helium bottle through bubbling on the stream bottom (Supplementary data, Figure

168 A.1). A precision manometer and a pressure regulator ensured the stability of the

169 injection. The background helium concentration of both streams was around

$1708 \cdot 10^{-9} \mathrm{~mol} \mathrm{~L}^{-1}$. Upon injection, it increased to $1.10^{-7} \mathrm{~mol} \mathrm{~L}^{-1}$ in stream $\mathrm{A}$ and to

$1718.10^{-7} \mathrm{~mol} \mathrm{~L}^{-1}$ in stream B. $10 \mathrm{~kg}$ of $\mathrm{NaCl}$ were dissolved in a $300 \mathrm{~L}$ can filled with

172 stream water. The $\mathrm{NaCl}$ solution was then injected into the stream at a flow rate of

$1732 \mathrm{~L} \mathrm{~min}^{-1}$ using a peristaltic pump. The background electrical conductivity,

174 measured at the injection site, before and after the experiments, was $270 \mu \mathrm{S} \mathrm{cm}^{-1}$ in 
175 stream A and $204 \mu \mathrm{S} \mathrm{cm}^{-1}$ in stream B. Upon injection, it increased to $330 \mu \mathrm{S} \mathrm{cm}^{-1}$

176 in stream A and to $229 \mu \mathrm{S} \mathrm{cm}^{-1}$ in stream B.

\section{2.3. Measurement}

178 In-situ measurements of helium were performed using continuous flow membrane

179 inlet mass spectrometry (CF-MIMS). In-situ membrane inlet mass spectrometry has

180 been shown to improve the determination of gas exchange rate coefficients based on

181 tracer injections (Knapp et al. 2019). It was also used recently by Weber et al. (2019)

182 to derive gas exchange rate coefficients from direct measurements of dissolved

183 atmospheric gases. The CF-MIMS used here (modified from HPR40 - Hiden

184 Analytical) is described in details in Chatton et al. (2017). The gas inlet is ensured

185 by a membrane (X44® 99) connected to the vacuum of a Quadrupole Mass

186 Spectrometer (QMS around $10^{-5}$ Torr), allowing the direct permeation of dissolved

187 gases from water to spectrometer. Inside the QMS, gases are ionized using an oxide

188 coated iridium filament that allows the selection of ionization energies (between 4

189 and $150 \mathrm{eV}$ ) and emission intensities (between 20 and $5000 \mu \mathrm{A}$ ). Ionized gases are

190 then separated by the quadrupole according to their mass to charge ratios. Then, the

191 detection of gases is performed either by a Faraday cup or a single channel electron

192 multiplier (SCEM). The instrumental relative standard deviation is $2 \%$ for $\mathrm{He}$ and

$1930.2 \%$ for $\mathrm{N}_{2}, \mathrm{O}_{2}$ and $\mathrm{CO}_{2}$, indicating high measurement sensitivity.

194 The spectrometer was installed a few meters away from the stream. Stream water

195 was pumped continuously (MP1 Grunfoss pump, $5 \mathrm{~L} \mathrm{~min}^{-1}$ ) and brought to the

196 spectrometer membrane through a nylon tubing system preventing any contact with 
197 the air. The pump was attached to a float so that stream water was pumped at a

198 constant depth, approximately $10 \mathrm{~cm}$ below the surface. Helium was measured by

199 the spectrometer in real time, with a 10 second timestep. During injection, the pump

200 feeding the CF-MIMS was moved step by step from the downstream end to the

201 upstream end of the reach to map the loss of helium along the stream. To make sure

202 that the injection rate was constant, the pump was first installed at the downstream

203 end of the reach until helium concentrations reached a stable plateau for 20 minutes.

204 Then, the pump was moved a few meters upstream to the next measurement location.

205 After a few minutes of unstable measurements due to pump and tubing manipulation,

206 the helium concentration stabilized at a new stable plateau. From that time, the pump

207 was maintained at this location during 10 minutes to gather a significant number of

208 helium measurements (60 to 70) and make sure the injection rate was constant. Then

209 the pump was moved upstream to the next measurement location, and the procedure

210 was reiterated up to the uppermost measurement location. Moving the pump

211 upstream avoided perturbation from one measurement location to the next one. The

212 stability of the injection and the consistency of the measurements were checked

213 continuously using real-time data visualization provided by the in-situ CF-MIMS

214 system. This system allowed real-time mapping of the degassing taking place along

215 the streams. Major atmospheric gas concentrations $\left(\mathrm{N}_{2}, \mathrm{O}_{2}, \mathrm{Ar}, \mathrm{CO}_{2}\right)$, water vapor

216 pressure $\left(\mathrm{H}_{2} \mathrm{O}\right)$ and temperature were simultaneously measured with the CF-MIMS

217 to correct helium data for external and instrumental deviations. CF-MIMS data,

218 expressed in partial pressures in air, were converted into concentrations in water by 
219 external calibration with micro-gas chromatography $(\mu \mathrm{GC})$ measurements on grab

220 samples. Two samples intended for $\mu \mathrm{GC}$ analysis were taken at each location, in

$221500 \mathrm{~mL}$ glass bottles. To ensure the synchronicity of CF-MIMS and $\mu \mathrm{GC}$ data,

222 samples were collected directly at the CF-MIMS outlet. The tube filling the glass

223 bottles was immerged in a bucket to avoid any contact with the atmosphere. All $\mu \mathrm{GC}$

224 measurements were performed less than 48 hours after sampling. The instrument

225 relative standard deviation of the $\mu \mathrm{GC}$ is $3 \%$. Detailed description of CF-MIMS

226 measurements, corrections and the calibration procedure can be found in Chatton et

227 al. (2017). As a proxy for $\mathrm{NaCl}$, electrical conductivity was monitored using two

228 Hatch $^{\circledR}$ probes. The relative standard deviation of EC measurements is $5 \%$. One EC

229 probe was moved together with the pump. The probe and the pump were attached to

230 the same float to ensure they sampled the same water. The second EC probe was

231 permanently installed 10 meters downstream from the injection site to check the

232 stability of salt injection. The experimental set-up is summarized in figure 2. 


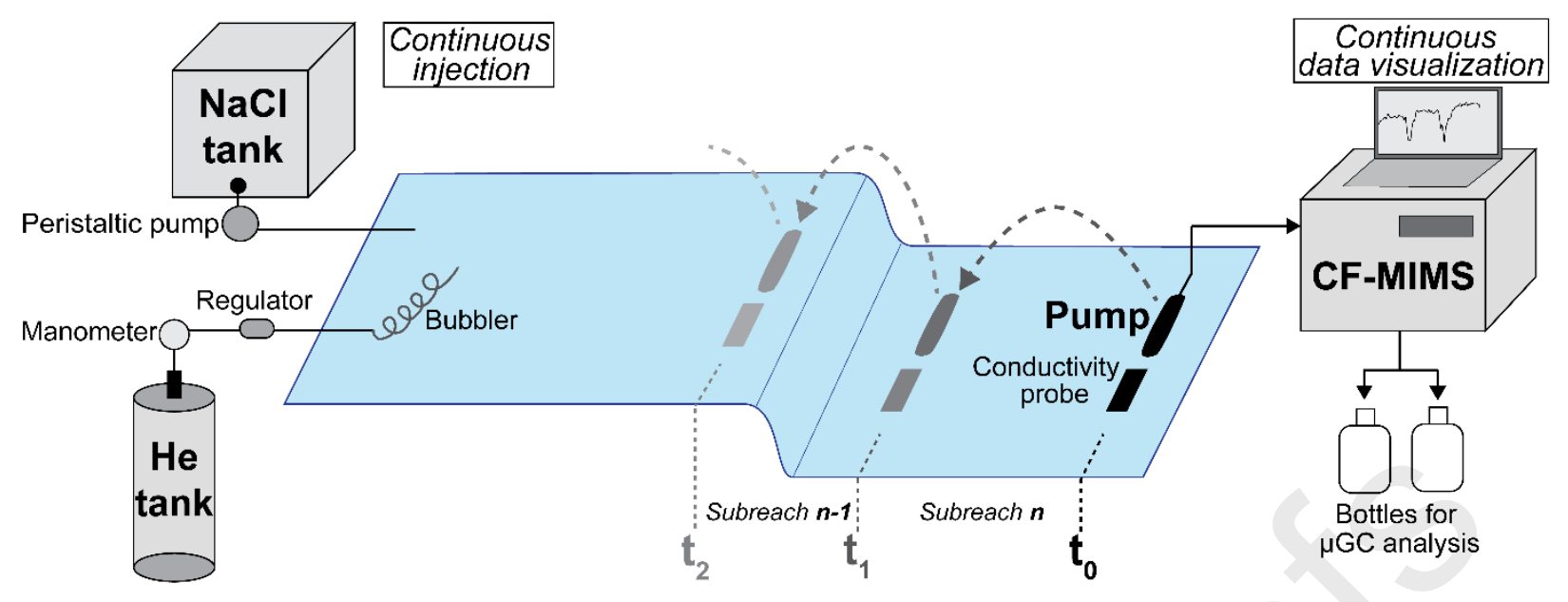

Figure 2. Experimental set up. Upstream, helium and salt are injected continuously at a stable level during the whole duration of the experiment. Downstream, at decreasing distances from the injection site, helium concentrations are measured continuously and visualized in real-time using a CF-MIMS fed by a pump. Chloride concentrations are measured with an EC probe. First, the pump and the EC probe are installed at the downstream end of the reach $\left(\mathrm{t}_{0}\right)$. Once the concentration in helium reaches a plateau, the pump and the EC probe are moved upstream to the next measurement location $\left(\mathrm{t}_{1}\right)$. Once a new plateau in concentration is reached, instruments are moved upstream again $\left(\mathrm{t}_{2}\right)$. The procedure is reiterated up until the last measurement location to map helium losses along the whole length of the reach. In order to calibrate CF-MIMS measurements, two bottles are sampled from the CF-MIMS outlet at each measurement location for $\mu \mathrm{GC}$ analysis. 
234 Degassing is commonly assumed to be linearly proportional to the air-water

235 concentration difference (Kilpatrick et al. 1987). Thus, the variation in helium

236 concentrations through time can be expressed by the 1D advection-dispersion

237 equation:

$$
\frac{\partial C_{H e}}{\partial t}+U \frac{\partial C_{H e}}{\partial x}=D_{x} \frac{\partial^{2} C_{H e}}{\partial x^{2}}-k_{H e}\left(C_{H e}-C_{H e}^{e q}\right)
$$

238 where $C_{H e}\left(\mathrm{~mol} \mathrm{~L}^{-1}\right)$ is the helium concentration, $C_{H e}^{e q}\left(\mathrm{~mol} \mathrm{~L}^{-1}\right)$ is the helium

239 concentration in a stream at equilibrium with the atmosphere, $k_{H e}\left(\mathrm{~s}^{-1}\right)$ is the air-water

240 gas exchange rate coefficient of helium, $U\left(\mathrm{~m} \mathrm{~s}^{-1}\right)$ is the water velocity and $D_{x}$

$241\left(\mathrm{~m}^{2} \mathrm{~s}^{-1}\right)$ is the longitudinal dispersion coefficient. Since helium has a low

242 atmospheric concentration, its equilibrium concentration in stream is low (around

$\left.2438.10^{-9} \mathrm{~mol} \mathrm{~L}^{-1}\right)$. Thus, during helium injections, stream helium concentration

244 becomes at least one order of magnitude higher than the equilibrium concentration,

245 and $C_{H e}^{e q}$ can be neglected. The variations in chloride concentrations through time can

246 be expressed using the same advection-dispersion equation without the degassing

247 term:

$$
\frac{\partial C_{C l}}{\partial t}+U \frac{\partial C_{C l}}{\partial x}=D_{x} \frac{\partial^{2} C_{C l}}{\partial x^{2}}
$$

248 where $C_{C l}\left(\mathrm{~mol} \mathrm{~L}^{-1}\right)$ is the chloride concentration. Assuming that the advection and 249 dispersion parameters for chloride are similar than for helium (Genereux and 250 Hemond 1992; Tobias et al. 2009; Wanninkhof et al. 1990), combining equations 1 
252 effects are taken into account by the ratio in chloride concentrations:

$$
k_{H e}=\frac{U}{L} \ln \left(\frac{\frac{\mathrm{C}_{H e}^{u p}}{\mathrm{C}_{H e}^{\text {down }}}}{\frac{\mathrm{C}_{C l}^{u p}}{\mathrm{C}_{C l}^{\text {down }}}}\right)
$$

253 where $\mathrm{C}_{\mathrm{He}}^{u p}$ and $\mathrm{C}_{\mathrm{Cl}}^{u p}\left(\mathrm{~mol} \mathrm{~L} \mathrm{~L}^{-1}\right)$ are the upstream concentrations, $\mathrm{C}_{\mathrm{He}}^{\text {down }}$ and $\mathrm{C}_{\mathrm{Cl}}^{\text {down }}$

$254\left(\mathrm{~mol} \mathrm{~L}^{-1}\right)$ are the downstream concentrations, $U\left(\mathrm{~m} \mathrm{~s}^{-1}\right)$ is the mean stream velocity 255 and $L(\mathrm{~m})$ is the distance between the two locations.

256 The gas exchanges depend on the nature of the gas and on water temperature. Gas 257 exchange rate coefficients can be scaled from one gas to another using the ratio of 258 their Schmidt numbers (Jähne et al. 1987b). The Schmidt number (Sc) is a 259 dimensionless number corresponding to the ratio of kinematic viscosity to mass 260 diffusivity. To enable comparison with previously published results, gas exchange 261 rate coefficients calculated for helium, $k_{H e}$, are scaled to the reaeration rate 262 coefficient $k_{2}$, defined as the gas exchange rate coefficient for $\mathrm{O}_{2}$ at $20^{\circ} \mathrm{C}$ :

$$
k_{2}=k_{H e}\left(\frac{S c_{O_{2}}}{S c_{H e}}\right)^{-0,5}
$$

263 where $S c_{O 2}$ is the Schmidt number for oxygen at $20^{\circ} \mathrm{C}$ and $S c_{H e}$ is the Schmidt 264 number for helium at stream temperature. The equations from which the Schmidt 265 numbers used in this study were obtained are featured in table 1. 
Table 1. Schmidt numbers used in this study.

Gas Reference Equation

Wanninkhof

(1992)

He based on data $S c_{H e}=377.09-19.154 T+0.50137 T^{2}-0.005669 T^{3}$ from

Jähne et al.

(1987a)

Baird and

Davidson

(1962);

Carlson

$\mathrm{O}_{2} \quad$ (1911);

Raymond et

al. (2012);

Wise and

Houghton

(1966)

$\mathrm{CO}_{2}$ Wanninkhof (1992)

$$
S c_{O_{2}}=1568-86.04 T+2.142 T^{2}-0.0216 T^{3}
$$

\subsection{Comparison with predictive equations}

268 Gualtieri et al. (2002) performed a dimensional analysis to identify the physical 269 parameters that control gas exchange rate coefficients in streams. They showed that 270 gas exchange rate coefficients $k\left(\mathrm{~d}^{-1}\right)$ can be expressed as a direct function of the

271 Froude number $F r$, the channel slope $i$, the Reynolds number $R e$, the ratio between

272 the stream depth $h(\mathrm{~m})$, the mean velocity $U\left(\mathrm{~m} \mathrm{~s}^{-1}\right)$, and a dimensionless gas 273 exchange factor $\lambda$ :

$$
k=\frac{U}{h} \lambda[F r, i, R e]
$$




\section{Journal Pre-proofs}
with:
$F r=\frac{U}{\sqrt{g h}}$
$R e=\frac{U h}{v}$

274 where $g\left(\mathrm{~m} \mathrm{~s}^{-2}\right)$ is the gravitational acceleration and $v\left(\mathrm{~m}^{2} \mathrm{~s}^{-1}\right)$ is the kinematic

275 viscosity. Gualtieri et al. (2002) reformulated 20 empirical and semi-empirical

276 equations from literature as a function of these parameters. It was shown that all

277 equations physically contain the velocity over depth ratio, the slope and the Froude

278 number. Some of them additionally involve the Reynolds number. Their process-

279 based analysis pointed out that stream depth is a crucial parameter in any gas

280 exchange rate coefficient equation: it influences in the velocity over depth ratio as

281 well as the Froude and Reynolds numbers. Thus, application of these equations

282 implicitly assumes the existence of a water layer with a well-defined thickness. In

283 cascades, such a layer cannot be defined. A cascade can be seen as a succession of a

284 ramp, where gas exchanges occur at the free surface of the water layer, and a

285 receiving basin, in which gas exchanges are controlled by air bubbles (Cirpka et al.

286 1993). In the ramp section of the cascade, the supercritical flow regime implies that

287 the water layer is very thin and uneven. In the receiving basin portion of the cascade,

288 the falling jet penetrating the water generates high turbulence and uneven flows.

289 Thus, the empirical and semi-empirical equations of gas exchange rate coefficient

290 are theoretically not applicable in cascades. Cirpka et al. (1993) developed

291 alternative semi-empirical equations to describe gas exchanges specifically within

292 cascades in large rivers. Their equations account for gas exchanges through the free

293 surface and via air bubbles. They rely on four parameters, the calibration of which 
294 requires extensive in-situ tracer experiments with the simultaneous injections of four 295 different gases.

296 This raises the question of the suitability of predictive equations for global 297 estimations of gas exchange rate coefficients. Indeed, since most headwater streams 298 display both cascades and low turbulent zones, the unreliability of equations in 299 cascades is likely to distort the gas exchange rate coefficient at the stream scale. To 300 test if the presence of a few cascades significantly distorts global gas exchange 301 predictions over a stream reach, we compared measured $k_{2}$ values with values 302 calculated using predictive equations developed for small streams (table 2). We 303 considered the historical equation of O'Connor and Dobbins (1958). Among the 304 many other empirical equations that have been proposed ever since, we chose the 305 relationships that were calibrated with the largest datasets. The semi-empirical 306 equation from Melching and Flores (1999) is based on a large USGS data set and 307 was further used in several studies (Haider et al. 2013; Ritz et al. 2017). The seven 308 semi-empirical equations from Raymond et al. (2012) are based on the same USGS 309 data set and on four additional data sets (Bernot et al. 2010; Bott et al. 2006; 310 Mulholland et al. 2001; Tsivoglou and Neal 1976), making them, to our knowledge,

311 the equations based on the largest amount of data (Lauerwald et al. 2015). We also 312 considered the process-based equation proposed by Gualtieri and Gualtieri (2000) 313 and Gualtieri et al. (2002). 
Table 2. Predictive equations considered in this study. All formulas were converted into the reaeration rate coefficient $k_{2}\left(\mathrm{~d}^{-1}\right)$.

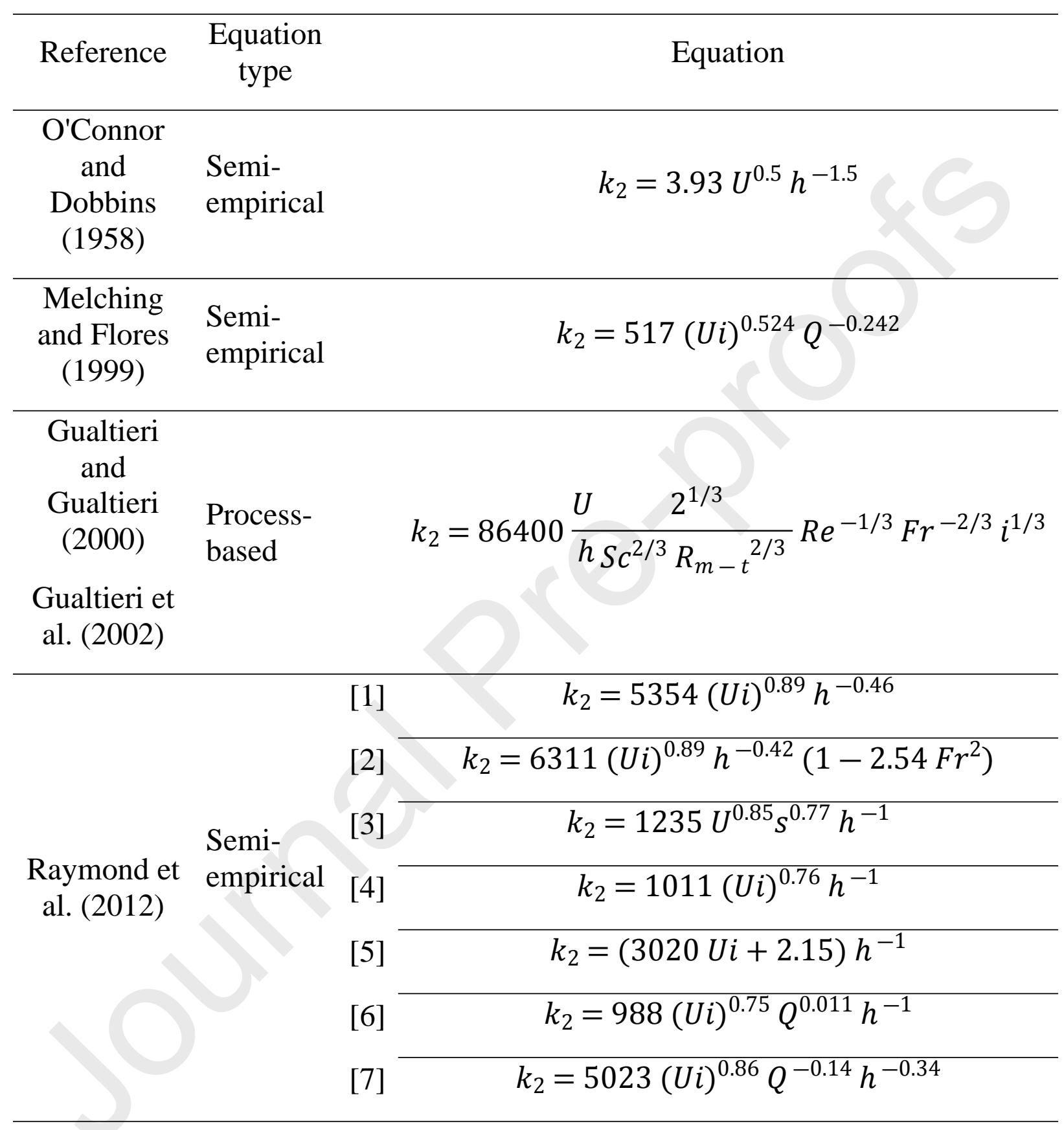

314 To compare measured gas exchange rate coefficients with gas exchange rate 315 coefficients obtained using predictive equations, the hydraulic parameters of each 316 stream were measured. (Supplementary data, Table A.1). Global parameters were 
317 evaluated at the reach scale and local parameters were evaluated for each sub-reach.

318 Stream discharge was calculated using a $\mathrm{NaCl}$ slug injection. Velocity was measured

319 using a field velocimeter (FP111 Global Water Flow Probe). The slope was derived

320 from the altitude gradient between upper and lower reach ends. Depth was measured

321 at several points across and along each reach, and averaged for each reach. 


\subsection{Reactive gases}

323 In conjunction with helium, $\mathrm{O}_{2}$ and $\mathrm{CO}_{2}$ were measured by CF-MIMS at several

324 distances from the injection site. Measurements were externally calibrated using

325 micro-gas chromatograph $(\mu \mathrm{GC})$ measurements, in the same way as for helium. In

326 both streams, the helium enrichment due to the injection was less than $1 \mu \mathrm{mol} \mathrm{L}{ }^{-1}$,

327 so it did not induce significant degassing of $\mathrm{O}_{2}$ or $\mathrm{CO}_{2}$. In stream $\mathrm{B}, \mathrm{O}_{2}$ and $\mathrm{CO}_{2}$

328 measurements failed because of a calibration error of the $\mu \mathrm{GC}$.

$329 \mathrm{CO}_{2}$ evasion was calculated using the measured $\mathrm{CO}_{2}$ concentrations and the gas

330 exchange rate coefficient derived from the helium injection. Gas exchange rate

331 coefficients were first converted from $\mathrm{He}$ to $\mathrm{CO}_{2}$ based on the ratio of their Schmidt

332 numbers (equation 4). The Schmidt number for $\mathrm{CO}_{2}$ is given in table 1 . The $\mathrm{CO}_{2}$

333 evasion rate at the stream-atmosphere interface $\left(\mathrm{mol} \mathrm{m}^{-2} \mathrm{~s}^{-1}\right)$ was then calculated

334 using the flux equation first developed for reaeration by Young and Huryn (1998)

335 and later derived for $\mathrm{CO}_{2}$ evasion (Billett et al. 2004; Hope et al. 2001; Öquist et al.

336 2009; Wallin et al. 2011):

$$
\mathrm{CO}_{2 \text { evasion }}=\left(\mathrm{CO}_{2 \text { stream }}-\mathrm{CO}_{2} \text { eq }\right) \times k_{\mathrm{CO}_{2}} \times \frac{Q}{U \times w}
$$


337 where $\mathrm{CO}_{2}$ stream is the measured $\mathrm{CO}_{2}$ concentration $\left(\mathrm{mol} \mathrm{L}^{-1}\right), \mathrm{CO}_{2}$ eq is the

338 concentration at equilibrium with the atmosphere $\left(\mathrm{mol} \mathrm{L}^{-1}\right), k_{\mathrm{CO} 2}$ is the gas exchange

339 rate coefficient for $\mathrm{CO}_{2}\left(\mathrm{~s}^{-1}\right), Q$ is the stream discharge $\left(\mathrm{L} \mathrm{s}^{-1}\right), U$ is the mean velocity

340 of the water $\left(\mathrm{m} \mathrm{s}^{-1}\right)$ and $w$ is the stream width $(\mathrm{m})$.

\section{$341 \quad 2.7$. List of the parameters}

342 The parameters used in the paper are listed in table 3.

Table 3. List of parameters used in the paper.

\begin{tabular}{|c|c|c|}
\hline Symbol & Variable & Unit \\
\hline$C_{C l}$ & concentration of chloride & mol L-1 \\
\hline$C_{C l}^{\text {down }}$ & downstream concentration of chloride & $\mathrm{mol} \mathrm{L}^{-1}$ \\
\hline$C_{C l}^{u p}$ & upstream concentration of chloride & $\mathrm{mol} \mathrm{L}-1$ \\
\hline$C_{H e}$ & concentration of helium & $\operatorname{mol~L} L^{-1}$ \\
\hline$C_{H e}^{e q}$ & $\begin{array}{l}\text { concentration of helium } \\
\text { at equilibrium with the atmosphere }\end{array}$ & mol L-1 \\
\hline$C_{H e}^{\text {down }}$ & downstream concentration of helium & mol L-1 \\
\hline $\mathrm{CH}_{\mathrm{He}}^{u p}$ & upstream concentration of helium & $\mathrm{mol} \mathrm{L}^{-1}$ \\
\hline$D_{x}$ & longitudinal dispersion coefficient & $\mathrm{m}^{2} \mathrm{~s}^{-1}$ \\
\hline$E$ & Aeration efficiency & [] \\
\hline$F r$ & Froude number & [] \\
\hline$g$ & standard acceleration due to gravity & $\mathrm{m} \mathrm{s}^{-2}$ \\
\hline$h$ & water depth & $\mathrm{m}$ \\
\hline$i$ & slope & [] \\
\hline$k$ & gas exchange rate coefficient & $\mathrm{s}^{-1}$ \\
\hline$k_{2}$ & $\begin{array}{l}\text { gas exchange rate coefficient for } \mathrm{O}_{2} \text { at } \\
20^{\circ} \mathrm{C} \\
\text { (also called reaeration rate coefficient) }\end{array}$ & $\mathrm{s}^{-1}$ \\
\hline
\end{tabular}




$\begin{array}{lll}k_{\mathrm{He}} & \begin{array}{l}\text { gas exchange rate coefficient for He } \\ \text { at the stream temperature }\end{array} & \mathrm{s}^{-1} \\ L & \text { stream length } & \mathrm{m} \\ Q & \text { stream discharge } & \mathrm{m}^{3} \mathrm{~s}^{-1} \\ R e & \text { Reynolds number } & {[]} \\ R_{m-t} & \begin{array}{l}\text { mass transfer Reynolds number } \\ \text { (fitted with data) }\end{array} & {[]} \\ S c_{C O 2} & \text { Schmidt number for } \mathrm{CO}_{2} & \\ S c_{H e} & \text { Schmidt number for } \mathrm{He} & {[]} \\ S c_{O 2} & \text { Schmidt number for } \mathrm{O}_{2} & {[]} \\ T & \text { stream temperature } & {[]} \\ t & \text { time } & { }^{\circ} \mathrm{C} \\ U & \text { Stream velocity } & \mathrm{s} \\ x & \text { Distance } & \mathrm{m} \mathrm{s}^{-1} \\ w & \text { Stream width } & \mathrm{m} \\ \lambda & \text { Dimensionless gas exchange factor } & {[]} \\ v & \text { kinematic viscosity } & \mathrm{m}^{2} \mathrm{~s}^{-1}\end{array}$

\section{RESULTS}

$344 \quad$ 3.1. Gas exchange mapping

345 In both streams (A and B), measurements at several distances from the injection

346 site show a decrease in helium concentrations from upstream to downstream

347 (figure 3). In stream A, the helium concentrations decrease from $140 \mathrm{nmol} \mathrm{L}^{-1}$ at

$34814 \mathrm{~m}$ from the injection site to $84 \mathrm{nmol} \mathrm{L}^{-1}$ at $52 \mathrm{~m}$ downstream. A light rain event

349 occurred at the end of the experiment, just before the pump was set up at the most

350 upstream measurement location $(9 \mathrm{~m})$. The rain increased the gas exchanges at the

351 stream surface (Ho et al. 2000), leading to lower helium concentrations at $9 \mathrm{~m}$ (130 
$\left.352 \mathrm{nmol} \mathrm{L}{ }^{-1}\right)$ than at $14 \mathrm{~m}\left(140 \mathrm{nmol} \mathrm{L}^{-1}\right)$. In stream B, helium concentrations decrease

353 from $820 \mathrm{nmol} \mathrm{L}^{-1}$ at $15 \mathrm{~m}$ from the injection site to $650 \mathrm{nmol} \mathrm{L}^{-1}$ at $98 \mathrm{~m}$

354 downstream. The CF-MIMS semi-continuous measurements allowed visualization

355 and quantification of the uncertainty in helium concentration estimates. The relative

356 standard deviation (RSD) of the 60 to 70 measurements available at each distance

357 was comprised between 1.7 and $4.5 \%$ in stream A, and between 0.9 and $1.5 \%$ in

358 stream B, attesting the stability of helium concentrations at each location. The lower

359 RSD in stream B is probably due to the higher helium injection rate. The large

360 number of measurements allows to perform a trend analysis on each plateau. It

361 reveals the absence of systematic decrease or increase of the helium concentration

362 upon a plateau (Supplementary data, Table A.2). In stream A, 4 plateaus have a slight

363 increasing trend and 3 plateaus have a slight decreasing trend. In stream B, 3 plateaus

364 have a slight increasing trend and one plateau has a slight decreasing trend. This

365 suggest an overall stability of the injection rate. Electrical conductivity can be

366 considered as stable along the streams, since its variation from upstream to

367 downstream is lower than the instrumental relative standard deviation. EC stability

368 thus shows the absence of major groundwater inputs prone to modify the helium

369 signal. In stream $\mathrm{A}$, where measurements of $\mathrm{O}_{2}$ and $\mathrm{CO}_{2}$ are available, the

370 consistency in the variations of $\mathrm{He}, \mathrm{O}_{2}$ and $\mathrm{CO}_{2}$ further confirms the absence of

371 disturbance of the gas content by groundwater inputs. $\mathrm{CO}_{2}$ concentrations in

372 groundwater, as measured at a small spring located 20 meters upstream from the

373 injection site, reach $650 \mu \mathrm{mol} \mathrm{L}^{-1}$, that is 30 times the atmospheric equilibrium. 
374 Inputs of such concentrated groundwater along the studied reach would have

375 induced a sharp increase in $\mathrm{CO}_{2}$ concentrations in the stream. However, $\mathrm{CO}_{2}$

376 concentrations follow a general decreasing trend, from at $299 \mu \mathrm{mol} \mathrm{L}^{-1}$ at $14 \mathrm{~m}$ to

$377288 \mu \mathrm{mol} \mathrm{L}^{-1}$ at $52 \mathrm{~m}$, suggesting that there are no major inputs of groundwater along

378 the studied reach. Salt injections had to be stopped before the end of the experiments

379 because of a deficit in salt injection solution. It is unlikely to bias the conclusions

380 reached here, as EC does not change between the downstream and upstream ends of

381 each studied reach (figure 3). 

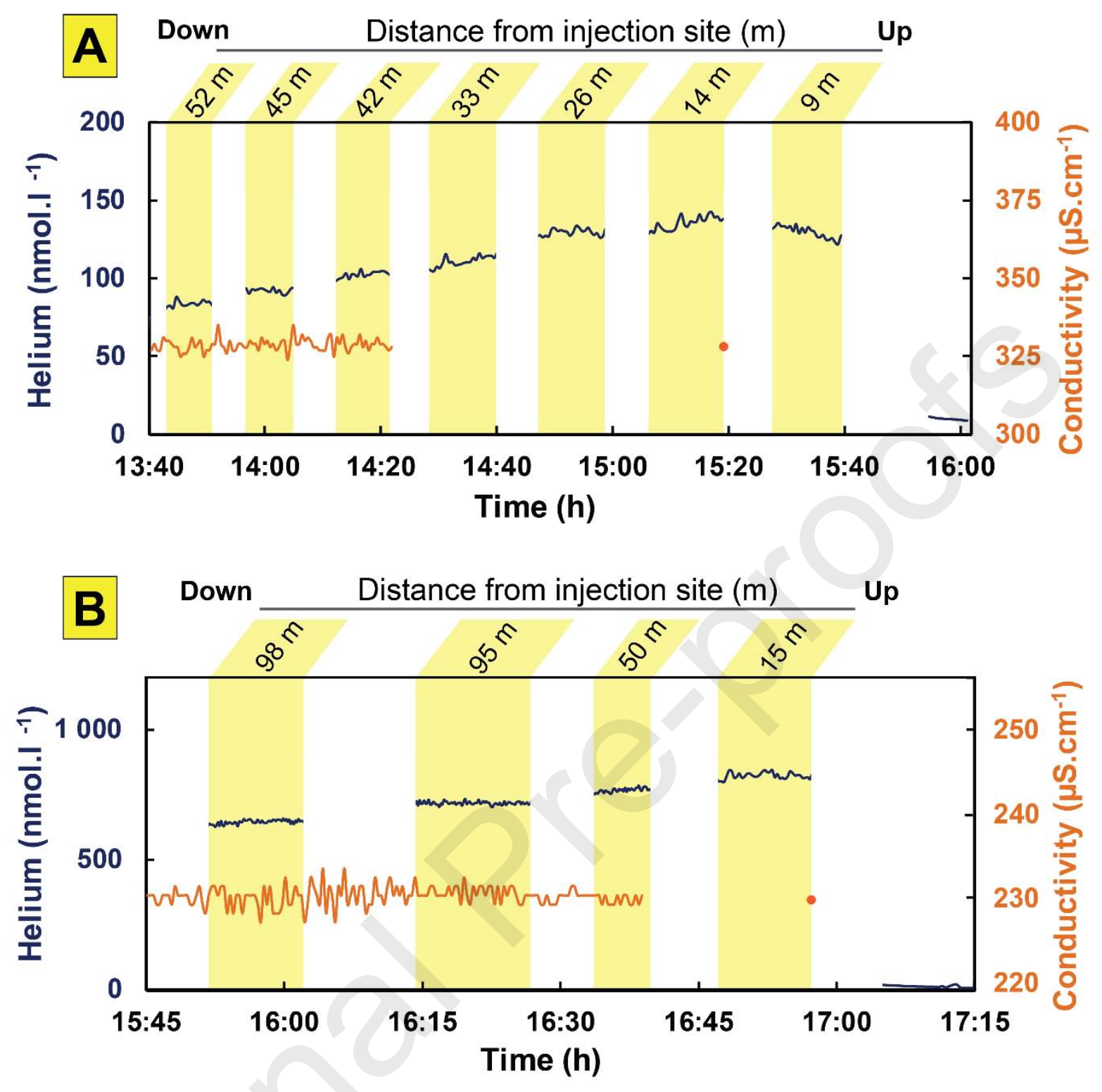
Figure 3. Monitoring of helium in stream A (up) and B (down). Blue lines represent the calibrated helium concentration, orange lines represent the electrical conductivity. Each plateau, highlighted by a yellow band, corresponds to a measurement location. Salt injection was stopped at 14:20 in stream A and at 16:40 in stream B. In stream A, it rained at the end of the experiment, when the pump was at $9 \mathrm{~m}$ from the injection site. Rain increased gas exchanges between stream and atmosphere thus lowering helium concentrations. The complete helium time series, including the measurements during the changes of measurement location, are presented in the Supplementary data, Figure A.2.

Global gas exchange rate coefficients in each stream were calculated using the concentration difference between the most upstream and downstream locations

384 (equation 3). Since EC does not vary along each stream, the ratio between upstream 385 and downstream chloride concentrations is equal to 1 and can be simplified in 386 equation 3. The gas exchange rate coefficient for helium, $k_{H e}$, was $196 \mathrm{~d}^{-1}$ in stream

387 A and $99 \mathrm{~d}^{-1}$ in stream $\mathrm{B}$, corresponding to a reaeration rate coefficient, $k_{2}$, of 388 respectively $130 \mathrm{~d}^{-1}$ and $60 \mathrm{~d}^{-1}$ (equation 4). These $k_{2}$ are in the range of values found 389 by other gas tracer release experiments in headwater streams (table 4). The 390 reaeration rate coefficient is significantly higher in the $1^{\text {st }}$ order stream (A) than in 391 the $2^{\text {nd }}$ order stream (B). It is consistent with the observations of Wallin et al. (2011) 392 showing an increase in the rate of $\mathrm{CO}_{2}$ degassing with lower stream order. 
Table 4. Reaeration rate coefficients measured in this study are in the range of reaeration rate coefficients from other gas tracer release experiments performed in headwater streams $\left(\mathrm{Q}<100 \mathrm{~L} \mathrm{~s}^{-1}\right)$.

\begin{tabular}{|c|c|c|c|}
\hline Reference & Gaseous tracer & $\begin{array}{c}\text { Non-volatile } \\
\text { tracer }\end{array}$ & $k_{2}\left(\mathrm{~d}^{-1}\right)$ \\
\hline This study, stream A & He & chloride & 130 \\
\hline This study, stream B & He & chloride & 60 \\
\hline $\begin{array}{l}\text { Wanninkhof et al. } \\
\text { (1990) }\end{array}$ & $\mathrm{SF}_{6}$ & ${ }^{3} \mathrm{H}_{2} \mathrm{O}$ & 119 \\
\hline $\begin{array}{l}\text { Genereux and Hemond } \\
\text { (1992) }\end{array}$ & $\begin{array}{l}\text { propane, } \\
\text { ethane }\end{array}$ & chloride & $118-139$ \\
\hline Soares et al. (2013) & propane & rhodamine WT & $27-367$ \\
\hline Benson et al. (2014) & $\mathrm{SF}_{6}, \mathrm{Xe}$ & - & $47-66$ \\
\hline Knapp et al. (2019) & $\begin{array}{l}\text { propane, } \\
\text { krypton }\end{array}$ & fluorescein & $15-134$ \\
\hline
\end{tabular}

393 For each sub-reach, reaeration rate coefficients were calculated in the same way as 394 for the full stream reaches. Helium concentrations and reaeration rate coefficients 395 were then reported as a function of the distance from injection site (figure 4). 396 Uncertainties in the helium concentrations were estimated by the standard deviations 397 of the 60 to 70 CF-MIMS measurements available for each plateau. Standard 398 deviations are small (figure 4), demonstrating the robustness of the measurements. 399 Uncertainties in the gas exchange rate coefficients were estimated by randomly 400 subsampling each plateau of helium concentration. The gas exchange rate coefficient 401 was calculated using a randomly chosen value of the upstream plateau and a 
402 randomly chosen value of the downstream plateau. The random sampling was

403 reiterated 1000 times for each sub-reach, leading to $1000 \mathrm{k}_{2}$ values. The standard

404 deviation of the $1000 \mathrm{k}_{2}$ values indicated the uncertainty due to helium measurement

405 (figure 4). The uncertainty is smaller in stream B than in stream A, due to the lower

406 noise level in stream B. A big advantage of the continuous measurements with in-

407 situ CF-MIMS is that it produces a significant number of measurements, which

408 allows to visualize and quantify the uncertainties. For the sub-reaches where EC was

409 available, the uncertainty due to EC measurements was quantified in the same way,

410 by sub-sampling EC values from each plateau. Taking into account the uncertainty

411 due to EC measurements increased the standard deviation by $50 \%$ in sub-reach $A_{5}$,

412 by $8 \%$ in sub-reach $A_{6}$ and by $10 \%$ in sub-reach $B_{3}$. Thus, the uncertainty due to EC

413 measurements is lower than the uncertainty due to helium measurements, but is not

414 negligible. When possible, we recommend using a fluorescent dye as conservative

415 tracer, rather than $\mathrm{NaCl}$. The measurement accuracy of fluorescent dyes is usually

416 higher, and florescent dyes are not present naturally in water, which lowers the

417 overall uncertainty on gas exchange rate coefficients.

418 The gas exchanges are heterogeneously distributed along the streams. In stream A, $419 k_{2}$ increases by a factor of 6 from the less turbulent zones $\left(k_{2}\left(\mathrm{~A}_{2}\right)=50 \mathrm{~d}^{-1}\right.$; $\left.420 k_{2}\left(\mathrm{~A}_{4}\right)=70 \mathrm{~d}^{-1}\right)$ to the highest cascade $\left(k_{2}\left(\mathrm{~A}_{5}\right)=360 \mathrm{~d}^{-1}\right)$. Intermediary values are

421 found in the sub-reach displaying three successive small cascades $\left(k_{2}\left(\mathrm{~A}_{3}\right)=220 \mathrm{~d}^{-1}\right)$

422 and in the agitated sub-reach with no identifiable cascade $\left(k_{2}\left(\mathrm{~A}_{6}\right)=140 \mathrm{~d}^{-1}\right)$. Thus,

423 reaeration rate coefficients are ranked according to the level of turbulence. In stream 
$424 \mathrm{~B}$, the range of reaeration rate coefficients is larger. The reaeration rate coefficient 425 is 40 times higher in the cascade $\left(k_{2}\left(\mathrm{~B}_{3}\right)=1030 \mathrm{~d}^{-1}\right)$ than in the flat area $426 \quad\left(k_{2}\left(\mathrm{~B}_{1}\right)=k_{2}\left(\mathrm{~B}_{2}\right)=25 \mathrm{~d}^{-1}\right)$. Note that the first two sub-reaches $\mathrm{B}_{1}$ and $\mathrm{B}_{2}$, presenting 427 visually the same morphological characteristics, have the same $k_{2}$ values, which 428 supports the reliability of the method. This mapping of gas exchanges evidences a 429 high heterogeneity of degassing along the streams. Exchanges are strongly focused 430 in cascades: a $35 \mathrm{~cm}$ high cascade loses as much gas as an $80 \mathrm{~m}$ long low-turbulent 431 reach. 

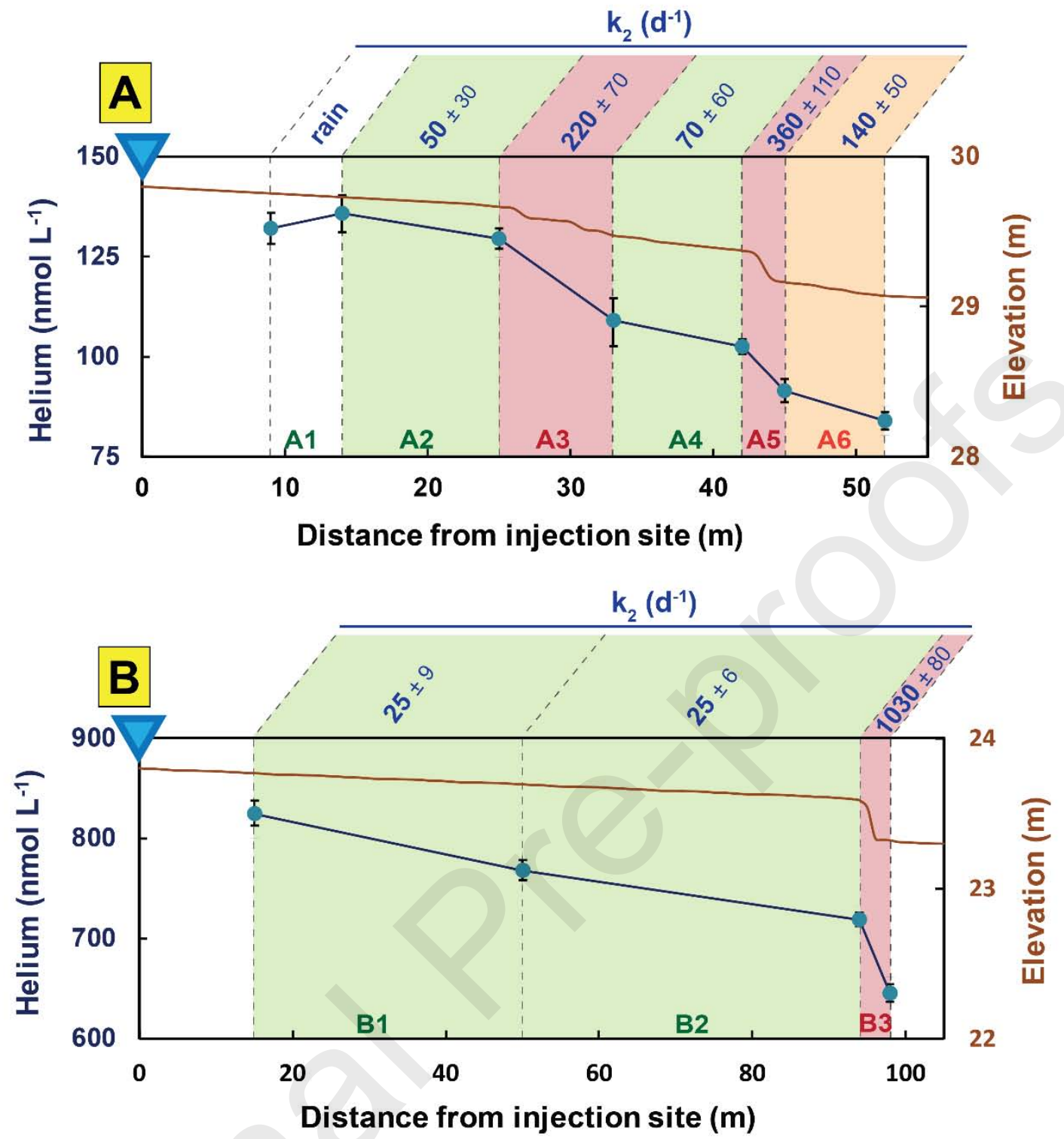

injection site low turbulence
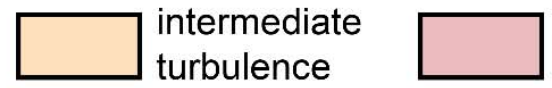
cascade 
Figure 4. Helium loss along stream A (top) and stream B (bottom) as a function of the distance from the injection site. Helium concentrations were calculated at each location as the average of the plateau highlighted in figure 3. In stream A, it rained at the end of the injection, inducing higher gas exchanges between stream and atmosphere that lowered helium concentrations measured at $9 \mathrm{~m}$ from injection site. Error bars in the helium concentration represent $\pm \sigma$. On top of each graph, reaeration rate coefficients are given $\left(k_{2}\right)$. The confidence intervals of the reaeration rate coefficient, determined by a subsampling of each plateau of helium concentration, represent $\pm \sigma$.

\subsection{Suitability of predictive equations}

The ten predictive equations given in table 2 were applied to the streams A and B

434 using the hydraulic parameters given in table A.1. At the reach scale, the ten 435 predictive equations systematically underestimate reaeration rate coefficients, by a

436 factor comprised between 1.2 and 2.2 (figure 5). Reaeration rate coefficients were

437 also calculated for each sub-reach using the local hydraulic parameters. The mean 438 and standard deviation of the ten predicted $k_{2}$ values (obtained with the ten equations 439 of table 2) are given in table 5. On average, predictive equations strongly 440 underestimate gas exchanges in the cascade sub-reaches, while they are consistent 441 in low-turbulent zones. The spread of the $k_{2}$ values given by the different equations, 442 indicated by their standard deviation, is also significantly higher in cascades than in 443 low-turbulent zones. Elevated differences between predicted and measured $k_{2}$ values 
444 in cascades are due to the fact that physically, predictive equations are non-reliable

445 in high-turbulent zones (section 2.5). They are based on parameters that are highly

446 difficult to measure in cascades such as the stream depth. The underestimation of

447 predicted reaeration rate coefficients in cascades significantly biases the predictions

448 at the full-reach scale, leading to a systematic underestimation of global gas

449 exchanges.

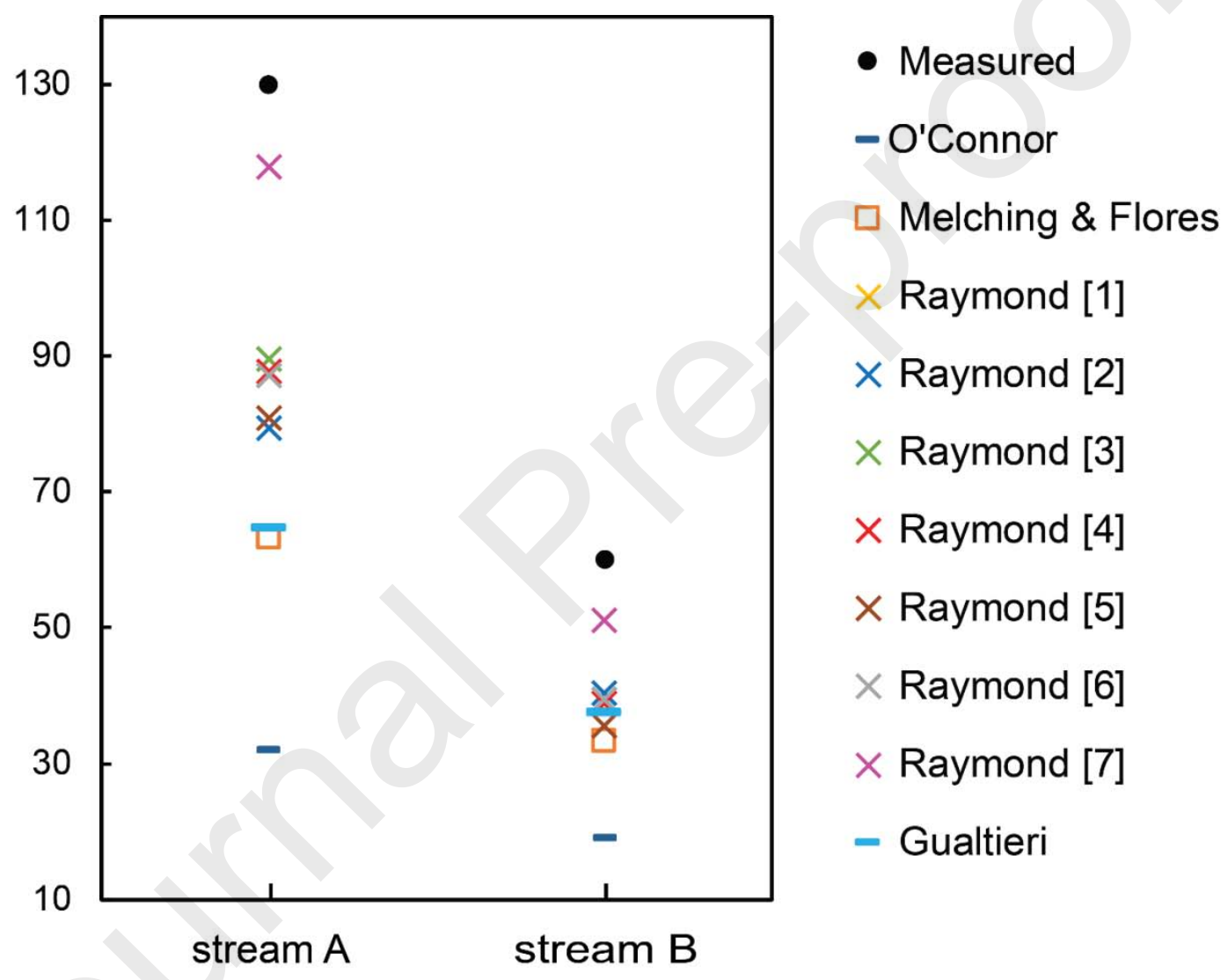

Figure 5. Predictive equations systematically underestimate the reaeration rate coefficient measured at the full-reach scale. 


\section{Journal Pre-proofs}

Table 5. Comparison of predicted and measured reaeration rate coefficients in each sub-reach. The mean and standard deviation of the predicted $k_{2}$ derive from the statistics of the values obtained with the ten equations of table 2.

\begin{tabular}{cccccc}
\hline $\begin{array}{c}\text { Strea } \\
\mathrm{m}\end{array}$ & $\begin{array}{c}\text { Sub- } \\
\text { reach }\end{array}$ & $\begin{array}{c}\text { Agitation } \\
\text { level }\end{array}$ & $\begin{array}{c}\text { Measured } k_{2} \\
\left(\mathrm{~d}^{-1}\right)\end{array}$ & $\begin{array}{c}\text { Mean of the } \\
\text { predicted } k_{2}\left(\mathrm{~d}^{-}\right. \\
1)\end{array}$ & $\begin{array}{c}\text { Standard deviation } \\
\text { of the predicted } k_{2} \\
\left(\mathrm{~d}^{-1}\right)\end{array}$ \\
\hline & A2 & calm & 50 & 47 & 8 \\
& A3 & cascade & $\mathbf{2 2 0}$ & $\mathbf{1 1 1}$ & $\mathbf{3 8}$ \\
$\mathrm{A}$ & A4 & calm & 70 & 61 & 13 \\
& A5 & cascade & $\mathbf{3 6 0}$ & $\mathbf{1 8 9}$ & $\mathbf{8 1}$ \\
& A6 & $\begin{array}{c}\text { intermedia } \\
\text { te }\end{array}$ & 140 & 86 & 26 \\
& B1 & calm & 25 & 22 & 3 \\
B & B2 & calm & 25 & 22 & 3 \\
& B3 & cascade & $\mathbf{1 0 3 0}$ & $\mathbf{6 7 9}$ & $\mathbf{4 4 1}$ \\
\hline
\end{tabular}

\subsection{Impacts on reactive gases}

451 With a mean concentration of around $290 \mu \mathrm{mol} \mathrm{L}^{-1}$, stream A is oversaturated in

$452 \mathrm{CO}_{2}$, in the sense that it contains 10 times more $\mathrm{CO}_{2}$ than it would at equilibrium

453 with the atmosphere (figure 6). $\mathrm{CO}_{2}$ oversaturation is frequent in headwater streams,

454 because of inputs of groundwater that are highly concentrated in $\mathrm{CO}_{2}$ due to the 455 aerobic degradation of organic matter (Cole et al. 2007). Water-rock interaction can 456 also be a source of $\mathrm{CO}_{2}$ in streams, especially in karst regions (Chen et al. 2004).

457 The large excess of $\mathrm{CO}_{2}$ in stream A originates from a small spring that flows 20 458 meters upstream from the injection site. The spring water has a $\mathrm{CO}_{2}$ concentration 
459 reaching $650 \mu \mathrm{mol} \mathrm{L}-1$, which is 30 times higher than the atmospheric equilibrium.

460 Contrariwise, stream A shows an undersaturation in $\mathrm{O}_{2}$ (figure 6). Its $\mathrm{O}_{2}$

461 concentration is comprised between 280 and $300 \mu \mathrm{mol} \mathrm{L}^{-1}$, while at equilibrium with

462 the atmosphere it would be $344 \mu \mathrm{mol} \mathrm{L}^{-1}$. Undersaturation in $\mathrm{O}_{2}$ is common in

463 headwater streams because they are mostly net heterotrophs (Knapp et al. 2015;

464 Riley and Dodds 2012; Young and Huryn 1999). In cascades, the state of the stream

465 is rapidly modified by strong exchanges of gas following partial pressure gradients.

$466 \mathrm{CO}_{2}$ oversaturation induces significant drops in $\mathrm{CO}_{2}$ in cascades, while $\mathrm{O}_{2}$

467 undersaturation induces gains in $\mathrm{O}_{2}$ (figure 6). Release of $\mathrm{CO}_{2}$ to the atmosphere, as

468 well as stream oxygenation, mainly occurs in the cascades. Note that the rain event

469 that occurred when the pump was at $9 \mathrm{~m}$ from the injection site increased gas 
470 exchanges, leading to a drop in $\mathrm{CO}_{2}$ concentration and an increase in $\mathrm{O}_{2}$ 471 concentration.

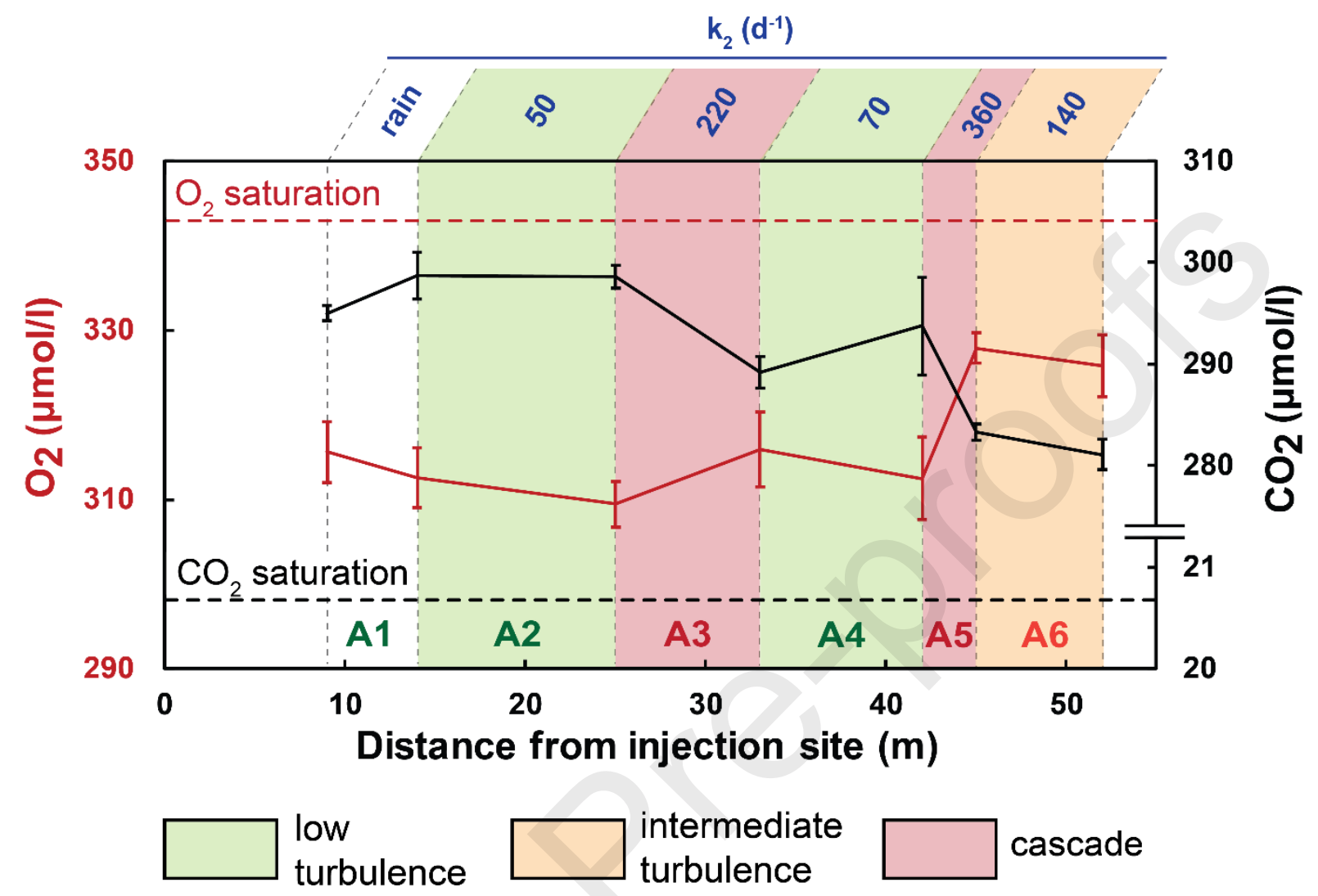

Figure 6. Cascades induce a rapid gain of $\mathrm{O}_{2}(\mathrm{red})$ and release of $\mathrm{CO} 2$ (black) along stream A. Errors bars represent $\pm \sigma$. Dashed lines indicate $\mathrm{O}_{2}$ (red) and $\mathrm{CO}_{2}$ (black) equilibrium with the atmosphere. $k_{2}$ values obtained by helium injection are recalled on the top of the graph and area colors indicate the visually-determined level of turbulence.

473 coefficient measured with helium and converted to $\mathrm{CO}_{2}$ (equation 4), we estimated 474 the global $\mathrm{CO}_{2}$ evasion rate of stream $\mathrm{A}$ at $47 \mu \mathrm{mol} \mathrm{m}^{-2} \mathrm{~s}^{-1}$ (equation 6). This 475 corresponds to $48 \mathrm{gC} \mathrm{m}^{-2} \mathrm{~d}^{-1}$, which is close to the evasion rate of $56 \mathrm{gC} \mathrm{m}^{-2} \mathrm{~d}^{-1}$ that 
was measured in a Canadian steep headwater stream by direct $\mathrm{CO}_{2}$ injections

477 (McDowell and Johnson 2018). The $\mathrm{CO}_{2}$ evasion rate of stream A was also

478 calculated using the gas exchange rate coefficients predicted by the empirical

479 equations of table 2. It yielded systematically lower $\mathrm{CO}_{2}$ evasion rates, comprised

480 between 16 and $44 \mathrm{gC} \mathrm{m}^{-2} \mathrm{~d}^{-1}$ (table 6). Thus, the underestimation of gas exchange

481 rate coefficients by empirical equations (section 3.2.) leads to a significant

482 underestimation of the $\mathrm{CO}_{2}$ flux from headwater streams.

If $\mathrm{CO}_{2}$ concentrations in the stream were modified solely by gas exchanges

484 with the atmosphere, the calculated evasion rate of $48 \mathrm{gC} \mathrm{m}^{-2} \mathrm{~d}^{-1}$ would imply a

485 decrease of $50 \mu \mathrm{mol} \mathrm{L}-1$ in the $\mathrm{CO}_{2}$ concentration between the upstream and the 486 downstream end of the reach $\mathrm{A}$. This is higher than the measured net loss of $\mathrm{CO}_{2}$,

487 close to $20 \mu \mathrm{mol} \mathrm{L}^{-1}$ (Figure 6), showing that other processes, such as oxygenic 488 respiration, partly counterbalance the loss of $\mathrm{CO}_{2}$ to the atmosphere. It highlights

489 that the $\mathrm{CO}_{2}$ evasion rates cannot be derived directly from the changes in $\mathrm{CO}_{2}$ 490 concentration along the streams. 
Table 6. $\mathrm{CO}_{2}$ evasion rate in stream $\mathrm{A}$ derived from the gas exchange rate coefficients obtained with the equations of table 2. Predictive equations of gas exchange rate coefficients lead to an underestimation of $\mathrm{CO}_{2}$ evasion rate.

\begin{tabular}{|c|c|}
\hline $\begin{array}{c}\text { Gas exchange coefficient } \\
\text { based on }\end{array}$ & $\begin{array}{l}\mathrm{CO}_{2} \text { evasion rate } \\
\left(\mathrm{gC} \mathrm{m}^{-2} \mathrm{~d}^{-1}\right)\end{array}$ \\
\hline This experiment & 48 \\
\hline O'Connor and Dobbins (1958) & 16 \\
\hline Melching and Flores (1999) & 24 \\
\hline $\begin{array}{c}\text { Gualtieri and Gualtieri (2000) } \\
\text { Gualtieri et al. (2002) }\end{array}$ & 23 \\
\hline \multirow{7}{*}{$\begin{array}{l}\text { Raymond et al. } \\
\text { (2012) }\end{array}$} & 29 \\
\hline & 29 \\
\hline & 33 \\
\hline & 33 \\
\hline & 30 \\
\hline & 32 \\
\hline & 44 \\
\hline
\end{tabular}

\section{DISCUSSION}

\subsection{Predictions of gas exchanges}

493 Comparison between measured and predicted $k_{2}$ values demonstrates that the

494 presence of a few cascades along a stream significantly biases global predictions of 495 gas exchange, leading to a systematic underestimation of reaeration rate coefficients.

496 This is consistent with the study of Ulseth et al. (2019), showing, at stream scale, 
497 that empirical models underestimate gas exchanges in high-channel slope streams.

498 McDowell and Johnson (2018) also highlighted, when studying a headwater stream,

499 that models underestimate gas exchange rate coefficients for high $k$ values.

500 Processes governing gas exchanges in cascades fundamentally differ from those in

501 flowing sections (section 2.5). In cascades, air bubbles have a strong control over

502 gas exchanges (Chanson 1995; Chanson and Toombes 2002; Cirpka et al. 1993).

503 Overlooking specific processes occurring in cascades leads to an underestimation of

504 gas exchanges in headwater catchments, where shallow streams often display natural

505 cascades. Increasing the reliability of predictions would require separate

506 consideration of low-turbulent zones and cascades. For low-turbulent stream

507 sections, our study confirms the predictive capacities of the empirical and semi-

508 empirical equations of table 2. For cascades, predictions are more challenging and

509 require additional morphological characterization or field experiments. Studies

510 focused on spillways in flumes (Baylar et al. 2006; Essery et al. 1978; Gameson

511 1957; Gulliver et al. 1998; Khdhiri et al. 2014; Tebbutt 1972; Toombes and Chanson

512 2005) and on dams (Caplow et al. 2004; Gamlin et al. 2001) or cascades (Cirpka et

513 al. 1993) in rivers, use the aeration efficiency $E$ instead of the gas exchange rate

514 coefficient $k$. Aeration efficiency was defined by Gameson (1957) and represents

515 the total change in gas concentration occurring in the cascade, normalized by the air-

516 water concentration gradient:

$$
E=\frac{C_{d o w n}-C_{u p}}{C_{e q}-C_{u p}}
$$




\section{Journal Pre-proofs}

517 where $C_{u p}\left(\mathrm{~mol} \mathrm{~L}^{-1}\right)$ is the upstream concentration, $C_{\text {down }}\left(\mathrm{mol} \mathrm{L}^{-1}\right)$ is the

518 downstream concentration and $C_{e q}\left(\mathrm{~mol} \mathrm{~L}^{-1}\right)$ is the dissolved gas concentration at

519 equilibrium with the atmosphere. Equations derived from lab experiments predict

520 aeration efficiency as a function of cascade total height and, if applicable, of

521 additional morphological parameters of the cascade such as the height of

522 intermediate steps, or the angle of the weir (Baylar and Bagatur 2006; Baylar et al.

523 2006; Baylar et al. 2011; Essery et al. 1978; Khdhiri et al. 2014). The morphological

524 characteristics of the hydraulic structure seem to be more reliable to predict aeration

525 in cascades than the depth of the water layer. However, if these morphological

526 characteristics are well-defined in flumes, they are much harder to describe properly

527 in natural streams, where cascades are made up of heterogeneous stones and pieces

528 of wood. For more accurate gas exchange quantification, direct measurements

529 remain necessary in cascades.

$530 \quad$ 4.2. Impact of cascades on groundwater discharge estimates

531 Groundwater discharge in streams is commonly quantified using the natural gas

532 tracer ${ }^{222} \mathrm{Rn}$. Some authors like Gilfedder et al. (2019) and Cartwright et al. (2014)

533 raised the question of the impact of the variability of turbulence on ${ }^{222} \mathrm{Rn}$ degassing

534 rate and thus on groundwater discharge estimation. Our study points out that

535 cascades, by generating a fast equilibration between the stream and the atmosphere,

536 erase an important part of the gaseous groundwater signal in the stream (e.g. Rn, He,

$537 \mathrm{Ar}, \mathrm{CO}_{2}, \mathrm{CH}_{4}, \mathrm{~N}_{2}, \mathrm{~N}_{2} \mathrm{O}$ ). A cascade that is a few tens of centimeters high can lose as

538 much gas as a hundred meter long stream. Since such cascades are very common in 
539 low-order streams, this is prone to yield an underestimation of the groundwater

540 discharge calculated by ${ }^{222} \mathrm{Rn}$ mass balances. The location of the cascades should be

541 taken into account when defining the ${ }^{222} \mathrm{Rn}$ sampling strategy and their number and

542 size between the up and down ${ }^{222} \mathrm{Rn}$ sampling locations minimized. Our results

543 suggest that in reaches without notable cascades, one can reasonably calculate the

$544{ }^{222} \mathrm{Rn}$ degassing rate with empirical equations. In reaches displaying notable

545 cascades, however, direct gas tracer experiments appear to be necessary.

$546 \quad$ 4.3. Hot spots of reaeration

547 Studies based on flume experiments recommend the use of dams in rivers subject

548 to eutrophication to enhance water reaeration (Tebbutt 1972). Our study shows that

549 natural cascades significantly increase the oxygenation of headwater streams. In this

550 way, they might strongly help sustaining aerobic metabolism, and thus provide a

551 crucial ecosystem service in headwater catchment subject to eutrophication (Dodds

552 and Smith 2016; Garnier and Billen 2007). Considered as reaeration hot spots, small

553 cascades have the potential to enhance measurably the ecological conditions of

554 eutrophic streams and might thus be considered in management and restoration

555 strategies (Palmer et al. 2005).

$556 \quad$ 4.4. Hot spots of $\mathrm{CO}_{2}$ emission

557 Most headwater streams are net sources of atmospheric $\mathrm{CO}_{2}($ Cole et al. 2007;

558 Marx et al. 2017). Indeed, organic matter respiration occurring in the contributing

559 compartments (aquifer, hyporheic zone, soil) and in the stream network itself is often

560 responsible for an oversaturation in $\mathrm{CO}_{2}(\mathrm{Cole}$ et al. 2007) compared to the 
equilibrium with the atmosphere. Drops in $\mathrm{CO}_{2}$ partial pressure in water after

562 cascades and highly turbulent zones have been evidenced in headwater

563 streams (Duvert et al. 2018; Leibowitz et al. 2017; Natchimuthu et al. 2017). In karst

564 systems, these drops have been linked to water softening (Chen et al. 2004). At a

565 much bigger scale, Liu et al. (2017) showed that $\mathrm{CO}_{2}$ outgassing from low-gradient

566 large rivers was strongly controlled by the geomorphology. Here, by simultaneously

567 mapping the loss of a gas tracer and the changes in $\mathrm{CO}_{2}$ concentration along a

568 headwater stream, we establish a direct link between streambed morphology, gas

569 exchanges, and $\mathrm{CO}_{2}$ release to the atmosphere. We show that cascades significantly

570 enhance gas exchanges, leading to a fast $\mathrm{CO}_{2}$ release to the atmosphere. In a study

571 focused on the temporal variability of gas exchanges, McDowell and Johnson (2018)

572 showed that $84 \%$ of $\mathrm{CO}_{2}$ emissions from a steep headwater stream occurred when

573 discharge was higher than the median. They suggested that high flow events, because

574 they increase turbulence, can be seen as "hot moments" of $\mathrm{CO}_{2}$ emission in

575 headwater streams (McClain et al. 2003). Here, we highlight the spatial variability

576 of $\mathrm{CO}_{2}$ emissions and show that similarly, by increasing gas exchanges, cascades

577 can be viewed as "hot spots" of $\mathrm{CO}_{2}$ emission in headwater streams.

578 If we assume the $19 \mathrm{~km}$-long first order stream network of our $35 \mathrm{~km}^{2}$ catchment

579 has the same $\mathrm{CO}_{2}$ emission rate as the studied stream $\mathrm{A}$, a rough estimate of the total

580 evasion of $\mathrm{CO}_{2}$ over all first-order streams of the catchment can be calculated. We

581 limit the upscaling to the first-order stream network of a small catchment, in which

582 we assume that on average, cascades have the frequency and the size of those of 
stream A. Predictive equations from table 2 would lead to a total $\mathrm{CO}_{2}$ emission comprised between 150 and $300 \mathrm{tC}^{\text {year }}{ }^{-1}$ with the mean of the outputs from the ten equations being $220 \mathrm{tC}$ year-1, while the measured gas exchange rate leads to a $\mathrm{CO}_{2}$ emission of $330 \mathrm{tC}_{\text {year }}{ }^{-1}$. Such a rough, first-order estimation indicates that the

587 prediction of gas exchange rate coefficients at a large-scale with empirical equations

588 is likely to induce a general underestimation of $\mathrm{CO}_{2}$ emission from headwater

589 catchments. Similarly, empirical equations probably lead to an underestimation of

590 the emission of other greenhouse gases such as $\mathrm{CH}_{4}$.

\section{CONCLUSION}

Using continuous helium injection, we mapped gas exchanges along two low-slope

593 headwater streams in a temperate catchment in Brittany (France). Our experimental

594 set-up took advantage of the real-time data visualization allowed by the in-situ CF-

595 MIMS. It highlights the new opportunities offered by this technology, in terms of 596 spatial as well as temporal characterization of gas exchange processes. The semi597 continuous measurements allow to visualize and to quantify the uncertainties.

598 We evidenced a high spatial variability of gas exchanges, related to the small-scale 599 heterogeneity of the streambed morphology, which is a characteristic feature of 600 headwater streams. During one of our tracer tests, a small cascade was responsible 601 for almost half of the helium loss, while it occupied less than $4 \%$ of the total stream 602 length. Nevertheless, the equations predicting the gas exchange rate coefficients in 603 headwater streams do not account for the specific processes governing gas 
604 exchanges in natural cascades. As a result, while empirical relationships perform

605 well in low-turbulent zones, they systematically underestimate gas exchange rate

606 coefficients as soon as small cascades are present. This highlights the necessity of

607 performing direct measurements of gas exchange rate coefficients in reaches

608 displaying cascades while low-turbulent zones can be efficiently characterized by

609 empirical equations.

610 Additional $\mathrm{CO}_{2}$ and $\mathrm{O}_{2}$ measurements highlighted that small cascades strongly

611 modify the chemical state of headwater streams. High gas exchange rate coefficients

612 allow a fast incorporation of $\mathrm{O}_{2}$ in the water and a fast release of $\mathrm{CO}_{2}$ to the

613 atmosphere. Thus, cascades sustain respiration by rebalancing $\mathrm{O}_{2}$ concentrations in

614 the stream. At the same time, they promote the evasion of the oversaturated $\mathrm{CO}_{2}$ to

615 the atmosphere. Finally, small natural cascades are hot spots for both stream

616 oxygenation and greenhouse gas emission. Rough calculations of $\mathrm{CO}_{2}$ emissions

617 showed that the use of empirical equations leads to an underestimation of global $\mathrm{CO}_{2}$

618 emissions from headwater streams. Since the small-scale morphological

619 heterogeneity is a characteristic feature of headwater streams, the upscaling effort

620 could be helped by a distinct consideration of cascades and low-turbulent sections.

621 The first step would be to separately characterize gas exchange processes in these

622 totally different hydrodynamic regimes. The second step would be to estimate the

623 proportion of these two regimes in the stream network. This could be helped by

624 innovative technologies such as LIDAR, allowing a fine-scale characterization of

625 the topography. 


\section{ACKNOLEDGMENTS}

$627 \mathrm{PhD}$ of Camille Vautier is funded by the French Ministry for Higher Education,

628 Research and Innovation. Most of the equipment, especially the CF-MIMS, was

629 funded by the CRITEX project (ANR-11-EQPX-0011). Analysis with $\mu$ GC were

630 performed within the CONDATE-EAU analytical platform in Rennes. Field work

631 was performed in the Long-Term Socio-Ecological Research (LTSER) site "Zone

632 Atelier Armorique". The authors thank Christophe Petton and Virginie Vergnaud for

633 their precious involvement in the field experiments and in the laboratory analysis.

634 We also greatly thank Madeleine Nicolas for the proof-reading of the manuscript.

635 We thank the four reviewers, including Jordan F. Clark, for constructive comments 636 and suggestions.

\section{APPENDIX A: supplementary data}

637 - Figure A.1: Photograph of the bubbling system

638 - Figure A.2: Entire time series of the monitoring of helium

639 - Table A.1: Hydraulic and morphologic characteristics of reaches A and B

640 - Table A.2: Test of the stability of the plateaus of helium concentration 
642

643

644

645

646

647

648

649

650

651

652

653

654

655

656

657

658

659

660

661

662

663

664

665

666

667

668

669

670

671

672

673

674

675

676

677

678

679
Aristegi, L., O. Izagirre \& A. Elosegi, 2009. Comparison of several methods to calculate reaeration in streams, and their effects on estimation of metabolism. Hydrobiologia 635(1):113-124 doi:10.1007/s10750-009-9904-8.

Avery, E., R. Bibby, A. Visser, B. Esser \& J. Moran, 2018. Quantification of Groundwater Discharge in a Subalpine Stream Using Radon-222. Water 10(2) doi:10.3390/w10020100.

Baird, M. H. I. \& J. F. Davidson, 1962. Annular jets-II: Gas absorption. Chemical Engineering Science 17(6):473-480 doi:https://doi.org/10.1016/00092509(62)85016-7.

Baylar, A. \& T. Bagatur, 2006. Experimental studies on air entrainment and oxygen content downstream of sharp-crested weirs. Water and Environment Journal 20(4):210-216 doi:10.1111/j.1747-6593.2005.00002.x.

Baylar, A., M. E. Emiroglu \& T. Bagatur, 2006. An experimental investigation of aeration performance in stepped spillways. Water and Environment Journal 20(1):35-42 doi:10.1111/j.1747-6593.2005.00009.x.

Baylar, A., M. Unsal \& F. Ozkan, 2011. GEP modeling of oxygen transfer efficiency prediction in aeration cascades. KSCE Journal of Civil Engineering 15(5):799-804 doi:10.1007/s12205-011-1282-x.

Benson, A., M. Zane, T. Becker, A. Visser, S. Uriostegui, E. DeRubeis, J. Moran, B. Esser \& J. Clark, 2014. Quantifying Reaeration Rates in Alpine Streams Using Deliberate Gas Tracer Experiments. Water 6(4):1013-1027 doi:10.3390/w6041013.

Bernot, M. J., D. J. Sobota, R. O. Hall Jr, P. J. Mulholland, W. K. Dodds, J. R. Webster, J. L. Tank, L. R. Ashkenas, L. W. Cooper, C. N. Dahm, S. V. Gregory, N. B. Grimm, S. K. Hamilton, S. L. Johnson, W. H. Mcdowell, J. L. Meyer, B. Peterson, G. C. Poole, H. M. Valett, C. Arango, J. J. Beaulieu, A. J. Burgin, C. Crenshaw, A. M. Helton, L. Johnson, J. Merriam, B. R. Niederlehner, J. M. O’brien, J. D. Potter, R. W. Sheibley, S. M. Thomas \& K. Wilson, 2010. Inter-regional comparison of land-use effects on stream metabolism. Freshwater Biology 55(9):1874-1890 doi:doi:10.1111/j.13652427.2010.02422.x.

Billett, M. F., S. M. Palmer, D. Hope, C. Deacon, R. Storeton-West, K. J. Hargreaves, C. Flechard \& D. Fowler, 2004. Linking land-atmosphere-stream carbon fluxes in a lowland peatland system. Global Biogeochemical Cycles 18(1) doi:10.1029/2003gb002058.

Bishop, K., I. Buffam, M. Erlandsson, J. Fölster, H. Laudon, J. Seibert \& J. Temnerud, 2008. Aqua Incognita: the unknown headwaters. Hydrological Processes 22(8):1239-1242 doi:10.1002/hyp.7049. 
Bott, T. L., D. S. Montgomery, J. D. Newbold, D. B. Arscott, C. L. Dow, A. K. Aufdenkampe, J. K. Jackson \& L. A. Kaplan, 2006. Ecosystem metabolism in streams of the Catskill Mountains (Delaware and Hudson River watersheds) and Lower Hudson Valley. J N Am Benthol Soc 25(4):1018-1044 doi:10.1899/0887-3593(2006)025[1018:Emisot]2.0.Co;2.

Caplow, T., P. Schlosser \& T. Ho David, 2004. Tracer Study of Mixing and Transport in the Upper Hudson River with Multiple Dams. Journal of Environmental Engineering 130(12):1498-1506 doi:10.1061/(ASCE)07339372(2004)130:12(1498).

Carlson, T., 1911. The diffusion of oxygen in water. Journal of the American Chemical Society 33(7):1027-1032 doi:10.1021/ja02220a002.

Cartwright, I., H. Hofmann, B. Gilfedder \& B. Smyth, 2014. Understanding parafluvial exchange and degassing to better quantify groundwater inflows using 222Rn: The King River, southeast Australia. Chemical Geology 380:4860 doi:10.1016/j.chemgeo.2014.04.009.

Chanson, H., 1995. Air-water gas transfer at hydraulic jump with partially developed inflow. Water Research 29(10):2247-2254 doi:https://doi.org/10.1016/00431354(95)00056-Q.

Chanson, H. \& L. Toombes, 2002. Air-water flows down stepped chutes: turbulence and flow structure observations. International Journal of Multiphase Flow 28(11):1737-1761 doi:https://doi.org/10.1016/S0301-9322(02)00089-7.

Chatton, E., T. Labasque, J. de La Bernardie, N. Guiheneuf, O. Bour \& L. Aquilina, 2017. Field Continuous Measurement of Dissolved Gases with a CF-MIMS: Applications to the Physics and Biogeochemistry of Groundwater Flow. Environ Sci Technol 51(2):846-854 doi:10.1021/acs.est.6b03706.

Chen, J., D. D. Zhang, S. J. Wang \& T. F. Xiao, 2004. Water self-softening processes at waterfall sites. Acta Geol Sin-Engl Ed 78(5):1154-1161.

Churchill, M. A., H. L. Elmore \& R. A. Buckingham, 1964. The prediction of stream reaeration rates. In Southgate, B. A. (ed) Advances in Water Pollution Research. Pergamon, 89-136.

Cirpka, O., P. Reichert, O. Wanner, S. R. Mueller \& R. P. Schwarzenbach, 1993. Gas exchange at river cascades: field experiments and model calculations. Environ Sci Technol 27(10):2086-2097 doi:10.1021/es00047a014.

Cole, J. J., Y. T. Prairie, N. F. Caraco, W. H. McDowell, L. J. Tranvik, R. G. Striegl, C. M. Duarte, P. Kortelainen, J. A. Downing, J. J. Middelburg \& J. Melack, 2007. Plumbing the Global Carbon Cycle: Integrating Inland Waters into the Terrestrial Carbon Budget. Ecosystems 10(1):172-185 doi:10.1007/s10021006-9013-8.

Cook, P. G., G. Favreau, J. C. Dighton \& S. Tickell, 2003. Determining natural groundwater influx to a tropical river using radon, chlorofluorocarbons and ionic environmental tracers. Journal of Hydrology 277(1-2):74-88 doi:10.1016/s0022-1694(03)00087-8. 
Crawford, J. T., N. R. Lottig, E. H. Stanley, J. F. Walker, P. C. Hanson, J. C. Finlay \& R. G. Striegl, 2014. CO2and CH4emissions from streams in a lake-rich landscape: Patterns, controls, and regional significance. Global Biogeochemical Cycles 28(3):197-210 doi:10.1002/2013gb004661.

Dodds, W. \& V. Smith, 2016. Nitrogen, phosphorus, and eutrophication in streams. Inland Waters 6(2):155-164 doi:10.5268/iw-6.2.909.

Duvert, C., D. E. Butman, A. Marx, O. Ribolzi \& L. B. Hutley, 2018. CO2 evasion along streams driven by groundwater inputs and geomorphic controls. Nature Geoscience 11(11):813-818 doi:10.1038/s41561-018-0245-y.

Essery, I. T. S., T. H. Y. Tebbutt \& S. K. Rajaratnam, 1978. Design of Spillways for Reaeration of Polluted Waters. CIRIA Report No 72, Jan London, UK:36.

Gameson, A. L. H., 1957. Weirs and aeration of rivers. J Inst Water Eng 11:477490.

Gamlin, J. D., J. F. Clark, G. Woodside \& R. Herndon, 2001. Large-Scale Tracing of Ground Water with Sulfur Hexafluoride. Journal of Environmental Engineering 127(2):171-174 doi:doi:10.1061/(ASCE)07339372(2001)127:2(171).

Garnier, J. \& G. Billen, 2007. Production vs. respiration in river systems: an indicator of an "ecological status". The Science of the total environment 375(1-3):110-24 doi:10.1016/j.scitotenv.2006.12.006.

Genereux, D. P. \& H. F. Hemond, 1990. Naturally Occurring Radon 222 as a Tracer for Streamflow Generation: Steady State Methodology and Field Example. Water Resources 26(12):3065-3075 doi:doi:10.1029/WR026i012p03065.

Genereux, D. P. \& H. F. Hemond, 1992. Determination of gas exchange rate constants for a small stream on Walker Branch Watershed, Tennessee. Water Resources Research 28(9):2365-2374 doi:doi:10.1029/92WR01083.

Gilfedder, B. S., I. Cartwright, H. Hofmann \& S. Frei, 2019. Explicit Modeling of Radon-222 in HydroGeoSphere During Steady State and Dynamic Transient Storage. Groundwater 57(1):36-47 doi:10.1111/gwat.12847.

Gleeson, T., A. H. Manning, A. Popp, M. Zane \& J. F. Clark, 2018. The suitability of using dissolved gases to determine groundwater discharge to high gradient streams. Journal of Hydrology 557:561-572 doi:10.1016/j.jhydrol.2017.12.022.

Goncalves, J., A. Silveira, G. B. Lopes, M. S. da Luz \& A. L. A. Simoes, 2017. Reaeration Coefficient Estimate: New Parameter for Predictive Equations. Water Air Soil Pollut 228(8):10 doi:10.1007/s11270-017-3491-5.

Gualtieri, C. \& P. Gualtieri, 2000. Field verification for a reaeration model in streams. Paper presented at the 4th International Conference On Hydroscience $\&$ Engineering, Seoul, Korea.

Gualtieri, C., P. Gualtieri \& G. P. Doria, 2002. Dimensional analysis of reaeration rate in streams. Journal of Environmental Engineering-Asce 128(1):12-18 doi:10.1061/(asce)0733-9372(2002)128:1(12). 
Gulliver, J., S., S. Wilhelms, C. \& K. Parkhill, L., 1998. Predictive Capabilities in Oxygen Transfer at Hydraulic Structures. Journal of Hydraulic Engineering 124(7):664-671 doi:10.1061/(ASCE)0733-9429(1998)124:7(664).

Haider, H., W. Ali \& S. Haydar, 2013. Evaluation of various relationships of reaeration rate coefficient for modeling dissolved oxygen in a river with extreme flow variations in Pakistan. Hydrological Processes 27(26):39493963 doi:10.1002/hyp.9528.

Hall, R. O. \& H. L. Madinger, 2018. Use of argon to measure gas exchange in turbulent mountain streams. Biogeosciences 15(9):3085-3092 doi:10.5194/bg-15-3085-2018.

Ho, D. T., W. E. Asher, L. F. Bliven, P. Schlosser \& E. L. Gordan, 2000. On mechanisms of rain-induced air-water gas exchange. Journal of Geophysical Research: Oceans 105(C10):24045-24057 doi:10.1029/1999jc000280.

Hope, D., S. M. Palmer, M. F. Billett \& J. J. C. Dawson, 2001. Carbon dioxide and methane evasion from a temperate peatland stream. Limnology and Oceanography 46(4):847-857 doi:doi:10.4319/lo.2001.46.4.0847.

Jähne, B., G. Heinz \& W. Dietrich, 1987a. Measurement of the diffusion coefficients of sparingly soluble gases in water. Journal of Geophysical Research 92(C10):10767 doi:10.1029/JC092iC10p10767.

Jähne, B., K. O. Münnich, R. Bösinger, A. Dutzi, W. Huber \& P. Libner, 1987b. On the parameters influencing air-water gas exchange. Journal of Geophysical Research: Oceans 92(C2):1937-1949 doi:doi:10.1029/JC092iC02p01937.

Khdhiri, H., O. Potier \& J. P. Leclerc, 2014. Aeration efficiency over stepped cascades: better predictions from flow regimes. Water Res 55:194-202 doi:10.1016/j.watres.2014.02.022.

Kilpatrick, F. A., R. E. Rathbun, N. Yotsukura, G. W. Parker \& L. L. DeLong, 1987. Determination of stream reaeration coefficients by use of tracers Open-File Report.

Knapp, J. L., K. Osenbruck \& O. A. Cirpka, 2015. Impact of non-idealities in gastracer tests on the estimation of reaeration, respiration, and photosynthesis rates in streams. Water Res 83:205-16 doi:10.1016/j.watres.2015.06.032.

Knapp, J. L. A., K. Osenbrück, M. S. Brennwald \& O. A. Cirpka, 2019. In-situ mass spectrometry improves the estimation of stream reaeration from gas-tracer tests. Science of The Total Environment 655:1062-1070 doi:https://doi.org/10.1016/j.scitotenv.2018.11.300.

Kolbe, T., J. Marcais, Z. Thomas, B. W. Abbott, J. R. de Dreuzy, P. RousseauGueutin, L. Aquilina, T. Labasque \& G. Pinay, 2016. Coupling 3D groundwater modeling with CFC-based age dating to classify local groundwater circulation in an unconfined crystalline aquifer. Journal of Hydrology 543:31-46 doi:10.1016/j.jhydrol.2016.05.020.

Lauerwald, R., G. G. Laruelle, J. Hartmann, P. Ciais \& P. A. G. Regnier, 2015. Spatial patterns in $\mathrm{CO}_{2}$ evasion from the global river network. Global Biogeochemical Cycles 29(5):534-554 doi:10.1002/2014gb004941. 
Leibowitz, Z. W., L. A. F. Brito, P. V. De Lima, E. M. Eskinazi-Sant'Anna \& N. O. Barros, 2017. Significant changes in water $\mathrm{pCO}_{2}$ caused by turbulence from waterfalls. Limnologica 62:1-4 doi:10.1016/j.limno.2016.09.008.

Liu, S., X. X. Lu, X. Xia, X. Yang \& L. Ran, 2017. Hydrological and geomorphological control on $\mathrm{CO} 2$ outgassing from low-gradient large rivers: An example of the Yangtze River system. Journal of Hydrology 550:26-41 doi:10.1016/j.jhydrol.2017.04.044.

Marx, A., J. Dusek, J. Jankovec, M. Sanda, T. Vogel, R. van Geldern, J. Hartmann \& J. A. C. Barth, 2017. A review of CO2 and associated carbon dynamics in headwater streams: A global perspective. Rev Geophys 55(2):560-585 doi:10.1002/2016rg000547.

McClain, M. E., E. W. Boyer, C. L. Dent, S. E. Gergel, N. B. Grimm, P. M. Groffman, S. C. Hart, J. W. Harvey, C. A. Johnston, E. Mayorga, W. H. McDowell \& G. Pinay, 2003. Biogeochemical Hot Spots and Hot Moments at the Interface of Terrestrial and Aquatic Ecosystems. Ecosystems 6(4):301312 doi:10.1007/s10021-003-0161-9.

McDowell, M. J. \& M. S. Johnson, 2018. Gas Transfer Velocities Evaluated Using Carbon Dioxide as a Tracer Show High Streamflow to Be a Major Driver of Total CO2 Evasion Flux for a Headwater Stream. Journal of Geophysical Research: Biogeosciences 123(7):2183-2197 doi:10.1029/2018jg004388.

Melching, C. S. \& H. E. Flores, 1999. Reaeration equations derived from US geological survey database. Journal of Environmental Engineering-Asce 125(5):407-414 doi:10.1061/(asce)0733-9372(1999)125:5(407).

Mulholland, P. J., C. S. Fellows, J. L. Tank, N. B. Grimm, J. R. Webster, S. K. Hamilton, E. Martí, L. Ashkenas, W. B. Bowden, W. K. Dodds, W. H. Mcdowell, M. J. Paul \& B. J. Peterson, 2001. Inter-biome comparison of factors controlling stream metabolism. Freshwater Biology 46(11):1503-1517 doi:doi:10.1046/j.1365-2427.2001.00773.x.

Natchimuthu, S., M. B. Wallin, L. Klemedtsson \& D. Bastviken, 2017. Spatiotemporal patterns of stream methane and carbon dioxide emissions in a hemiboreal catchment in Southwest Sweden. Sci Rep 7:39729 doi:10.1038/srep39729.

O'Connor, D. J. \& W. E. Dobbins, 1958. Mechanism of Reaeration in Natural Streams. Transactions of the American Society of Civil Engineers 123(1):641-666.

Öquist, M. G., M. Wallin, J. Seibert, K. Bishop \& H. Laudon, 2009. Dissolved Inorganic Carbon Export Across the Soil/Stream Interface and Its Fate in a Boreal Headwater Stream. Environ Sci Technol 43(19):7364-7369 doi:10.1021/es900416h.

Palmer, M. A., E. S. Bernhardt, J. D. Allan, P. S. Lake, G. Alexander, S. Brooks, J. Carr, S. Clayton, C. N. Dahm, J. Follstad Shah, D. L. Galat, S. G. Loss, P. Goodwin, D. D. Hart, B. Hassett, R. Jenkinson, G. M. Kondolf, R. Lave, J. L. Meyer, T. K. O'Donnell, L. Pagano \& E. Sudduth, 2005. Standards for 
ecologically successful river restoration. Journal of Applied Ecology 42(2):208-217 doi:10.1111/j.1365-2664.2005.01004.x.

Palumbo, J. E. \& L. C. Brown, 2014. Assessing the Performance of Reaeration Prediction Equations. Journal of Environmental Engineering 140(3):7 doi:10.1061/(asce)ee.1943-7870.0000799.

Raymond, P. A., C. J. Zappa, D. Butman, T. L. Bott, J. Potter, P. Mulholland, A. E. Laursen, W. H. McDowell \& D. Newbold, 2012. Scaling the gas transfer velocity and hydraulic geometry in streams and small rivers. Limnology and Oceanography: Fluids and Environments 2(1):41-53 doi:10.1215/215736891597669.

Riley, A. J. \& W. K. Dodds, 2012. Whole-stream metabolism: strategies for measuring and modeling diel trends of dissolved oxygen. Freshwater Science 32(1):56-69, 14.

Ritz, S., K. Dähnke \& H. Fischer, 2017. Open-channel measurement of denitrification in a large lowland river. Aquatic Sciences 80(1) doi:10.1007/s00027-017-0560-1.

Soares, P. A., G. Faht, A. Pinheiro, M. R. da Silva \& E. Zucco, 2013. Determination of reaeration-rate coefficient by modified tracer gas technique. Hydrological Processes 27(19):2710-2720 doi:10.1002/hyp.9371.

Tebbutt, T. H. Y., 1972. Some studies on reaeration in cascades. Water Research 6(3):297-304 doi:https://doi.org/10.1016/0043-1354(72)90007-3.

Tobias, C. R., J. K. Bohlke, J. W. Harvey \& E. Busenberg, 2009. A simple technique for continuous measurement of time-variable gas transfer in surface waters. Limnol Oceanogr Meth 7:185-195 doi:10.4319/lom.2009.7.185.

Toombes, L. \& H. Chanson, 2005. Air-Water Mass Transfer on a Stepped Waterway. Journal of Environmental Engineering 131(10):1377-1386 doi:doi:10.1061/(ASCE)0733-9372(2005)131:10(1377).

Tranvik, L. J., J. A. Downing, J. B. Cotner, S. A. Loiselle, R. G. Striegl, T. J. Ballatore, P. Dillon, K. Finlay, K. Fortino, L. B. Knoll, P. L. Kortelainen, T. Kutser, S. Larsen, I. Laurion, D. M. Leech, S. L. McCallister, D. M. McKnight, J. M. Melack, E. Overholt, J. A. Porter, Y. Prairie, W. H. Renwick, F. Roland, B. S. Sherman, D. W. Schindler, S. Sobek, A. Tremblay, M. J. Vanni, A. M. Verschoor, E. von Wachenfeldt \& G. A. Weyhenmeyer, 2009. Lakes and reservoirs as regulators of carbon cycling and climate. Limnology and Oceanography 54(6, part 2):2298-2314 doi:doi:10.4319/1o.2009.54.6_part_2.2298.

Tsivoglou, E. C. \& L. A. Neal, 1976. Tracer Measurement of Reaeration: III. Predicting the Reaeration Capacity of Inland Streams. Journal (Water Pollution Control Federation) 48(12):2669-2689.

Ulseth, A. J., R. O. Hall, M. Boix Canadell, H. L. Madinger, A. Niayifar \& T. J. Battin, 2019. Distinct air-water gas exchange regimes in low- and highenergy streams. Nature Geoscience 12(4):259-263 doi:10.1038/s41561-0190324-8. 
Wallin, M. B., M. G. Öquist, I. Buffam, M. F. Billett, J. Nisell \& K. H. Bishop, 2011. Spatiotemporal variability of the gas transfer coefficient $(\mathrm{KCO} 2)$ in boreal streams: Implications for large scale estimates of CO2evasion. Global Biogeochemical Cycles 25(3) doi:10.1029/2010gb003975.

Wanninkhof, R., 1992. Relationship between wind speed and gas exchange over the ocean. Journal of Geophysical Research 97(C5):7373 doi:10.1029/92jc00188.

Wanninkhof, R., P. J. Mulholland \& J. W. Elwood, 1990. Gas exchange rates for a first-order stream determined with deliberate and natural tracers. Water Resources Research 26(7):1621-1630 doi:doi:10.1029/WR026i007p01621.

Weber, U. W., P. G. Cook, M. S. Brennwald, R. Kipfer \& T. C. Stieglitz, 2019. A Novel Approach To Quantify Air-Water Gas Exchange in Shallow Surface Waters Using High-Resolution Time Series of Dissolved Atmospheric Gases. Environ Sci Technol 53(3):1463-1470 doi:10.1021/acs.est.8b05318.

Wise, D. L. \& G. Houghton, 1966. The diffusion coefficients of ten slightly soluble gases in water at $10-60^{\circ} \mathrm{C}$. Chemical Engineering Science 21(11):999-1010 doi:https://doi.org/10.1016/0009-2509(66)85096-0.

Young, R. G. \& A. D. Huryn, 1998. Comment: Improvements to the diurnal upstream-downstream dissolved oxygen change technique for determining whole-stream metabolism in small streams. Canadian Journal of Fisheries and Aquatic Sciences 55(7):1784-1785 doi:10.1139/f98-052.

Young, R. G. \& A. D. Huryn, 1999. Effects of land use on stream metabolism and organic matter turnover. Ecological Applications 9(4):1359-1376 doi:10.1890/1051-0761(1999)009[1359:Eoluos]2.0.Co;2. 
918 Camille Vautier: Conceptualization, Methodology, Investigation, Visualization, 919 Writing - Original Draft. Ronan Abhervé: Conceptualization, Methodology, 920 Investigation, Visualization. Thierry Labasque: Conceptualization, Methodology, 921 Investigation. Anniet M. Laverman: Writing - Review \& Editing. Aurélie Guillou: 922 Investigation. Eliot Chatton: Methodology, Investigation. Pascal Dupont: 923 Conceptualization. Luc Aquilina: Conceptualization, Writing - Review \& Editing. 924 Jean-Raynald de Dreuzy: Conceptualization, Writing - Review \& Editing, 925 Supervision.

\section{Declaration of interests}

928 The authors declare that they have no known competing financial interests or 929 personal relationships that could have appeared to influence the work reported in 930 this paper.

$932 \square$ The authors declare the following financial interests/personal relationships which 933 may be considered as potential competing interests:

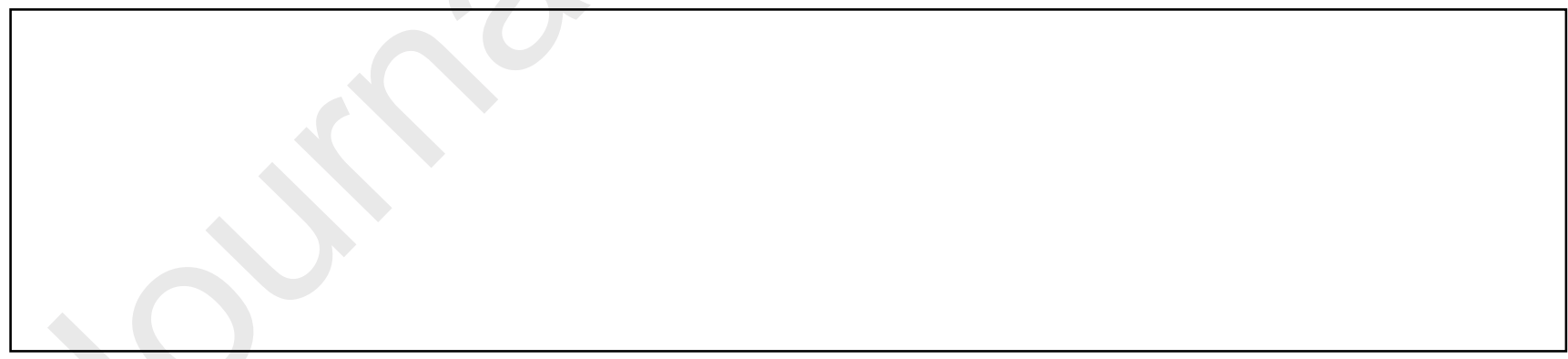


